\title{
Horizonte negativo da arte na era da saturação estética ${ }^{1}$
}

EUGÊNIO TRIVINHO

ECAVUSP e Universidade Católica de Santos 


\section{Resumo}

Inspirado no arco teórico que vai da Escola de Frankfurt ao pós-estruturalismo francês e ao pós-modernismo teórico, o presente ensaio discute a condição da arte no contexto social-histórico de excesso de produção tecnoestética, a partir da segunda metade do século XX. Na esteira (contra) metodológica de radicalização de todas as hipóteses de trabalho, como política de reflexão teórica voltada para a otimização da epistème, a argumentação traça os principais momentos da trajetória social-histórica da arte. Nesse quadro, a tendência da argumentação, no que toca à empiria estética, descarta tanto o apoio melancólico a formas, esquemas e contextos artísticos do passado, quanto sobretudo o apoio político-ufanista a formas, esquemas e contextos artísticos que reforçam o fetichismo estético integral, socialmente instituído; e, no que toca à teoria, evita tanto o essencialismo da estética moderna de Theodor Adorno, quanto o nilismo irônico do pós-modernismo de Jean Baudrillard acerca do destino da arte.

\section{Palavras-chave}

arte, capital, vida cotidiana; estética da mercadoria, estética da cultura tecnológica / fetichismo estético integral, valor estético; media, redes comunicacionais, significantes; excesso, auto-referencialidade, atelia

\section{Abstract}

Inspired in the theoretical arch that ranges from the School of Frankfurt to the French post-structuralism and to the theoretical post-modernism, this essay discusses the condition of art in the socio-historical context of excessive techno-aesthetic production commenced in the second half of the $20^{\text {th }}$ Century. On the (counter) methodological course of radicalizing all work hypotheses, such as the theoretical reflection policy aimed at optimizing the epistème, the argumentation traces the main moments of the art sociohistorical trajectory. In this picture, the tendency of argumentation, insofar as the aesthetic empiria is concerned, discards both the melancholic support for forms, schemes and artistic contexts of the past, and, most especially, the political-euphemistic support for the forms, schemes and artistic contexts that reinforce the socially-instituted integral aesthetic fetishism; and, insofar as theory is concerned, avoids both the essentialism of Theodor Adomo's modern aesthetics and Jean Baudrillard's post-modernism ironical nihilism regarding the destine of art.

\section{Key words}

art, capital, day-to-day life; aesthetics of merchandise, aesthetics of technological culture / integral aesthetic fetishism, aesthetic value; media, communicational networks, significant; excess, self-referentiality, athelia 
Olha em volta vê a vida ao redor -

Na morte! Viva!

Fala a verdade quem sombras fala.

Paul Celan (1999, p. 59)

\section{I - Arte, capital e vida cotidiana}

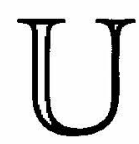

m olhar histórico-retrospectivo nos domínios da produção estética evidencia que a arte, como fenômeno ontoantropológico, ${ }^{2}$ nunca cultivou neutralidade e sua autonomia sempre foi efêmera. Liberta da função de culto no mundo

1. A publicação do presente ensaio, escrito especialmente para a revista Significação, requer esclarecimentos preliminares.

O argumento fundamental do texto foi concebido há aproximadamente dez anos, tendo esse vislumbre, desde então, produzido, no autor, efeitos intelectuais buliçosos, sem, no entanto, obter - em meio à massa de atividades acadêmicas regulares -, a devida atenção no tocante ao aprofundamento teóricoepistemológico, a formalização ensaística e a canalização pública. Parte da argumentação não deixou de ser, à época, previamente registrada; consta aqui integralizada em alguns subtópicos, os mesmos que, registre-se, pertencem a obra mais orgânica, Estética da cultura tecnológica: obliteraçóes, volume de continuação a Redes: obliterações no fim de século (1998a), cujo lançamento deverá se efetivar nos próximos años.

A oportuna retomada do argumento deveu-se a injunções do próprio contexto social-histórico contemporâneo: suas condições estruturais, ao invés de, no lastro do último decênio, terem sofrido reveršões substanciais a ponto de descartar ou anular as teses principais do texto, aprofundaram-se ainda mais, com o desenvolvimento acelerado e a proliferação diversificada das tecnologias áudio/ visuais e das demais técnicas de reprodução, bem como com a contínua acolhida em massa das reverberações socioculturais desses recursos instrumentais.

A argumentação, calcada numa macro-hipótese ao nível do objeto estudado, foi inteiramente revisada, estruturalmente ampliada e estrategicamente levada às últimas conseqüências, na esteira da frutífera perspectiva (contra)metodológica de radicalização teórico-epistemológica das hipóteses de trabalho. Dessa maneira, imprimiu-se no texto - crê-se -, o desenvolvimento e a recontextualização teóricos possíveis para o momento. As reformulações feitas, não raro para além do mero aspecto formal - aí sobretudo compreendida a faixa das notas de 
tribal, da tutela da mitologia cristã, da moralidade metafísica e da função de divertimento nas cortes aristocráticas, a arte teria conseguido conquistar uma autonomia através da qual expressaria, mais vigorosamente, seu poder crítico. Mas eis que, com o desenvolvimento tecnológico, ela se deparou talvez com o seu jugo mais severo, ao ser incorporada ao processo de produção: com todos os matizes e formas, com todas as combinações e qualidades, ela se compromete inteiramente com o capital em sua fase tecnológica avançada, alienando de

rodapé, a que se conferiu status de outro texto, nem sempre conexo ao fluxo principal da reflexão, embora, nem por isso, secundário - não interferiram no fundamento da argumentação, tal como originalmente concebida. Complementações teóricas, por sua vez, mesmo que em número e grau incontáveis, também se fizeram fiéis a tal viga mestra.

Nutrido pela tensa migração de valor cognitivo que envolve, exponencialmente, em seu arco, a (avaliação da já em boa conta comprometida) teoria crítica da Escola de Frankfurt (em matéria de estética), o pós-estruturalismo francês (por via das sinuosidades do pensamento de Jean Baudrillard, nas quais a argumentação foi, a rigor, inspirada) e o pós-modernismo teórico, o ensaio é o retrato de uma preocupação intelectual no âmbito da analítica do contexto social-histórico de fundo da arte, vale dizer, do contexto no qual ela se insere - a estética socialmente proliferada -, seja como processo criador, seja como produto final deste, a objetalidade da obra (esteja ela atrelada à severidade do tempo da longa duração ou às flexões do efêmero). Como tal, o texto não poderia furtar-se à crítica do movimento coletivo da própria produção estética, tenha ele caráter aleatório ou planejado. Essas propensões teóricas encontram-se já bem concentradas no título, explicitamente alusivo ao de uma das obras de Paul Virilio, L'horizon négatif: essai de dromoscopie (1984) - similitude que, com efeito, cessa na esfera da nomenclatura, posto que o presente ensaio aborda temática diversa da analisada pelo pensador francês.

No diâmetro de sua temática central - que, deve-se reconhecer, não deixa de já ser um tanto clássica -, o ensaio permanece como peça típica do período entre-séculos, distribuindo, por este epicentro temporal (que recobra a condição social-histórica pós-45), o seu alcance cognitivo e crítico tanto para as últimas décadas, quanto para as próximas (para recortar do tempo histórico futuro o que se enquadra apenas na cláusula do "curto prazo", por assim dizer). Não se trata, portanto, de um ensaio de circunstância.

Ao contrário do que possa parecer, a argumentação não foi formalizada para polemizar (como é, expressamente, o caso de outras peças ensaísticas do autor). A elaboração do texto regeu-se, quando muito - por mais controversas e propositalmente provocantes que sejam as teses trabaihadas - pelo princípio da necessidade intelectual de cumprir a exposição epistemológica de um pensamento teórico fustigado por seu próprio desejo de poiesis. Isso se imputa menos, absolutamente menos, à plena consciência do autor acerca das carências e lacunas do texto do que ao fato de aquele princípio ter prefigurado como valor de veracidade e transparência no momento do respectivo labor teórico. (Trata-se de típico escrito daqueles mobilizados contra o si próprio, porém sem resistências, eis que também posto à luz muito pouco contra a própria vontade.) Notação que não significa, nem de longe, subtração autoral a possiveis polêmicas desintencionais, que o ofício intelectual manda assumir tout court, por mais que as temáticas vinculadas à estética, sedutoras em si, figurem, com efeito, em paralelidade à linha de pesquisa que tem consumido todo o trabalho teórico do autor desde meados da década passada, a saber, a crítica da cultura pósmoderna, da cibercultura e do cyberspace, na perspectiva de um pós-teleologismo epistemológico radical (cf. Trivinho, 2001, p. 34, 165-174). 
novo sua autonomia a um desígnio cujo controle é socialmente realizado a partir de um locus exterior à própria produção estética.

\section{Arte na produção de mercadorias}

No século XX, o desenvolvimento das maquinarias e das técnicas de reprodução gráfica condicionou a criação propriamente artística a se transformar, em larga escala, em atividade de profissionais especializados ligada à produção de mercadorias. Escasso no início, o mercado de trabalho recebeu amplo estímulo e se expandiu, a partir de meados do século passado, com o advento da então chamada indústria cultural. $^{3}$

Nesse contexto, dois processos começaram a se paralelizar: de um lado, as criações artísticas não vinculadas diretamente à produção industrial, como a pintura tradicional, passam a ser reproduzidas em série e cada um de seus exemplares, a ser mercantilizado - são convertidos em "bens culturais", não por acaso um eufemismo -; de outro lado, as criações artísticas vinculadas à produção industrial passam a se hipostasiar no corpo das mercadorias, para fazê-las mais sedutoras e, assim, favorecer a realização de seu valor de troca.

A diferença entre um caso e outro não é, por certo, apenas de matiz. Enquanto, no primeiro, opera-se uma reprodução serial da arte por meio da tecnologia, no segundo há uma incorporação literal da mesma ao processo produtivo. Seja como for, a resultante é idêntica: a arte vê-se barganhada, senão cooptada - inclusive sob o concurso de seus representantes -, pela produção e se subordina às necessidades do mercado, da acumulação ampliada e da reprodução histórica do capital; mistura-se, assim, inteiramente, ao valor de troca. No segundo processo, em especial, a arte, homogeneamente embaralhada (em todos os níveis) com a razão técnica, marca presença de maneira virtualmente totalizante, a sua tessitura se convertendo em mera

2. Para efeito do presente ensaio, a noção de arte, tomada em sentido lato, compreende todas as modalidades sociais de manifestação estética do espírito. Em conceitos sintético-representativos: iconografia, forma, textura, sonoridade $\theta$ verbo. O conjunto da argumentação não deixa, porém, de evocar e/ou enfatizar mais as artes áudio/visuais.

3. Na acepção que então Ihe deram Theodor W. Adorno e Max Horkheimer (1970, p. 146-200). 
produção de efeitos estéticos: ela se enuncia desde a concepção da forma e design dos objetos (tomados em sentido genérico) até a definição de sua composição cromática e a elaboração de sua embalagem; numa palavra, ela vive desde o interior à casca do processo produtivo, tudo planejado - conforme sugerido - com vistas à otimização do produto no mercado. Nessas condições, a reverberação social da arte é bastante pródiga: o espaço urbano, a casa, os corpos são, por conseguinte, estetizados, ainda que - em vista de considerações teóricas a serem assentadas adiante - tal reverberação abranja apenas parcialmente os contextos sociais, por atrelagem a uma cintilação específica, a da própria mercadoria.

\section{Arte na vida cotidiana - fetichismo estético integral}

O excurso anterior mostra, suficientemente, que, do ponto de vista filosófico, a incorporação da arte ao processo produtivo e a sua reprodução serial por meio da tecnologia - ambos os processos fomentados pela circulação e reciclagem aceleradas de mercadorias - conduzem a um acontecimento culturalmente mais significativo: a arte, justamente por sua anexação à lógica do valor de troca, mesclase inextricavelmente à realidade existente; em palavras enfáticas, a simbiose entre arte e vida cotidiana.

Esse acontecimento, por sua natureza, seu ineditismo histórico e sua velocidade de realização extensiva, assombrou os teóricos da Escola de Frankfurt. Por trás da inserção da arte na esfera da produção, figurava, na verdade, a confusão entre cultura e racionalidade técnica, esta pensada em sua versão intrumental-capitalista. Theodor Adorno e Herbert Marcuse, num debate frutífero que envolveu Walter Benjamin como interlocutor, ${ }^{4}$ discutiram amplamente a cooptação da arte pela técnica para demonstrar que a sociedade tecnológica avançada apresentava um definido caráter totalitário.

Na perspectiva dos teóricos de Frankfurt, a arte, como fenômeno (produto, acontecimento e processo) era identitária à utopia, esfera em que a transcendência e a liberdade formam unidade indissolúvel;

4.Como se sabe, o debate inicia-se no final dos anos 30 e se estende para além da morte de Adorno, em 1969. Vários textos lhe deram forma e definiram seus rumos. Marcuse, além de ter corrigido suas posições depois do nazismo, escreveu menos 
e a vida cotidiana, na medida em que se entrelaça estruturalmente ao capital e pressupõe, nesse contexto, a luta pela sobrevivência, era associada à necessidade, esfera em que a liberdade consta desde sempre comprometida. Duas dimensões diametralmente opostas. Com efeito, a arte encerrava um princípio segundo o qual, pudesse ela, em algum momento histórico, conjuminar-se, sem coação ou repressão de qualquer espécie, com a realidade, esta certamente não seria mais o reino da necessidade, mas o da liberdade. A inserção da arte no aparato técnico extensivo da realidade conferiria a esta estatuto de outro porte, ao mesmo tempo que tal mescla haveria de figurar como termômetro fidedigno de aferição de uma mutação desse quilate. Mais ainda, o resultado final da incorporação - sem coação, nem repressão - da arte à realidade (vale lembrar, do reino da liberdade e da utopia ao reino da necessidade) deveria transparecer como verdadeira conciliação. Segundo Adorno e Marcuse, não foi isso, porém, o que ocorreu na sociedade tecnológica avançada. O que houve foi um rapto da arte por sedução instrumental dessa sociedade, uma cooptação sutilizada da cultura (entendida na acepção de produções do espírito) pela técnica, ao arrepio da liberdade e da transcendência. ${ }^{5}$ A junção dos dois pólos se realizou como se fosse algo natural, espontâneo, livre de problemas. Justificou, com efeito, a mobilização da categoria da crítica por parte dos teóricos de Frankfurt: nenhuma dissuasão factual poderia prosperar porque se tratava, claramente, do que eles nomearam como "falsa conciliação". Se a arte era, fundamentalmente, sublimação de pulsões, como Marcuse a entendia, então a sociedade

que Adorno a respeito. De Marcuse, vejam-se "Acerca del caráter afirmativo de la cultura" (1970a, p. 45-78); "Comentários acerca de uma nueva definición de la cultura" (1970b, p. 157-180); A dimensão estética (s/d.b); e "A arte na sociedade unidimensional" (1978, p. 243-256); De Adorno (com Horkheimer), vejam-se Dialéctica del iluminismo (1970, p. 146-200); e Teoria estética (s/d.); De Benjamin, veja-se, especialmente, "A obra de arte na época de sua reprodutibilidade técnica" (1978, p. 209-244). Esses textos expressam bem a natureza do debate. 5. Na vertente teórica oposta à da Escola de Frankfurt - como, de resto, à argumentação desenvolvida no presente ensaio (colisão que, ainda assim, se justifica, a título de afirmação do jogo dialético no universo do discurso teórico) -, comparece a desconcertante hipótese - fincada na seara do pós-estruralismo e do pósmodernismo, com inspiração em Baudrillard - segundo a qual o que houve, na verdade, foi um rapto do real (próprio do estágio tecnológico avançado) pela arte, em nome da perpetuação ampliada desta (como fenômeno autodiferenciado de outrora e, sobretudo, como campo de trabalho), mas de tal maneira que, em vista do contexto, a vitalidade e conseqüência da arte não podem mais se situar no horizonte dos objetos e processos inquestionados - fato que encerra toda a razão de ser do presente ensaio. O assunto é retomado no tópico III, mais adiante. 
tecnológica avançada, incorporando-a, instaurava não uma dessublimação normal, mas uma dessublimação repressiva (Marcuse, 1967, p. 81 e seg.; s/d.a, p. 176 e seg.), visto que se fazia - como a expressão o indica - de modo forçoso, por meio da coação técnica. Uma "conciliação verdadeira" não se realizaria através desse processo.

Se Adorno e Marcuse estavam em caminho teórico profícuo ou amplamente problemático ao insistir em tal concepção sobre a arte, não cabe ao presente ensaio julgar, nem dirimir. Nesse aspecto, o momento convida ao registro de que eles foram os únicos a testemunhar, com assiduidade, essa circunstância crucial da cultura (tomada agora em sentido mais geral, como environment socialmente construído). Ao tematizarem a relação da produção artística com o desenvolvimento avançado do valor de troca e com o real identitário a esse desenvolvimento, Adorno e Marcuse sabiam estar tangendo uma contradição irreversível da razão iluminista e que só tendia a se aprofundar. Operando para libertar o ente humano da esfera da necessidade, o iluminismo ${ }^{6}$ deveria deixar intocado aquilo que representava a liberdade, isto é, a arte, para que esta, como código de transcendência, pudesse servir-lhe de guia rumo à conquista do telos libertário. Mas eis que, na euforia de tantas conquistas tecnológicas, o iluminismo perverteu-se em seu movimento dialético e, ao invés de permanecer fiel ao seu projeto, fundou a arte ao princípio de realidade, asfixiando o seu conteúdo interno. Com isso, o iluminismo perdeu em, pelo menos, duas direções: em primeiro lugar, não conseguiu esconder seus intentos totalitários ao simular que a junção entre arte e técnica punha-se como verdadeira conciliação; em segundo lugar, sem uma transcendência radical em função da qual pudesse balizar seu percurso, acabou por se desorientar de vez, deixando-se dominar pela irracionalidade, paradoxalmente difundida num contex to social-histórico amplamente tecnicizado. O resultado de um iluminismo assim invertido, irracional e instrumental, equivale ao nazismo na política e à barbárie na cultura. ${ }^{7}$

6. "No sentido mais amplo do pensamento em contínuo progresso" (Adorno \& Horkheimer, 1970, p. 15).

7. Radica-se, nesses dados, o estereótipo (tanto jornalístico, quanto, infelizmente, acadêmico) de Adorno como filósofo pessimista. Contra estereótipos, surdos por princípio, é inútil - sabe-se - qualquer resposta. Cabe registrar, de toda 
Todavia, embora Adorno e Marcuse soubessem estar tematizando tal contradição da razão iluminista, não poderiam, obviamente, qualificar - no que concerne à forma e à aparência da realidade após a incorporação e reprodução da arte pela técnica - os rumos que o aprofundamento desse processo assumiria, nem prever aonde os acontecimentos, nesse plano, culminariam. Eis que, décadas depois, a arte, numa incrível metamorfose, estende-se para todas as áreas, freqüentando toda e qualquer produção. A essa altura - em que a estética já transcendeu o perímetro de irradiação dos e a partir dos objetos e serviços mercantis e passou a se apresentar sob novas facetas [por exemplo, através dos modelos e imagens artificiais (isto é, produzidas por meio de máquinas), em circulação proliferada, sob os auspícios das redes mediáticas] -, desenhase, ao nível social global, um fenômeno que, pela similaridade, muito evoca a conhecida reflexão de Marx (1983, p. 70 e seg.) sobre o fetiche em que se converte a mercadoria a partir de determinado estágio de desenvolvimento do capitalismo: o fetichismo estético integral, uma estetização acelerada, intensiva e extensiva de todos os objetos e corpos, ambientes, equipamentos arquitetônicos e metrópoles, processos e tendências. ${ }^{8}$ Nesse ponto, a realidade muda de estatuto e de escala: converte-se em hiper-realidade (Baudrillard, 1981, p. 9-68, especialmente, p. 10-11; e 1983, p. 11 e seg.), uma realidade mais real que o real, porque presidida pela estética, e que, por isso, já se apresenta como algo inteiramente diferente. ${ }^{9}$

Os indicadores acima não mostram senão que, na dimensão em questão, os acontecimentos rumaram - se assim se pode dizer -

forma, que é comum, no seio destes, a atribuição, com foros acusatórios, de "pessimismo" ao pensamento teórico avesso ao fantasma de qualquer ingenuidade em relação à lógica do sistema tecno-industrial-cultural instalado na segunda metade do século XX, ingenuidade que costuma acometer todas as ramificações contemporâneas do positivismo, sobretudo aquela, muito em voga, que faz da World Wide Web a morada de todas as apostas róseas no humano e o horizonte de todas as utopias egressas como que de uma tenra infância do pensamento.

8. Ressalve-se que o fetichismo estético integral nada tem a ver, a rigor, com a lógica da reflexão de Marx, uma vez que, sendo irreversível, tal fenômeno não implica nenhum esquema dialético de alienação/desalienaçāo, esquema que, por sua vez, pressupõe, no limite, o próprio processo revolucionário socialista (há décadas sem qualquer atmosfera de realização prática), nos termos fixados pelas várias correntes teleológico-políticas do marxismo.

9. Em Les stratégies fatales (1983), Baudrillard eleva todos os processos à potência superlativa: o mais feio que o feio, o monstruoso; o mais oculto que o oculto, 0 segredo (p. 7); mais belo que o belo, o fascinante (p. 8); mais social que o 
para muito longe do percebido e criticado pelos pensadores de Frankfurt, submetendo grande parcela de seus escritos a considerável defasagem teórica, a se levar em conta o momento tecnologicamente mais avançado do presente. ${ }^{10}$

\title{
II-Estética da cultura tecnológica e comunicação
}

\author{
"Vivemos num mundo em que a função mais elevada do signo é a de \\ fazer desaparecer a realidade e mascarar ao mesmo tempo essa \\ desaparição. A arte não faz hoje outra coisa. Os media não fazem hoje \\ outra coisa. É por isso que estão votados ao mesmo destino."
}

JEAN BAUDRILLARD (1996, p. 27-28)

A título de reescalonamento teórico e recontentextualização temática do objeto do presente ensaio, faça-se, neste tópico, uma reflexão de fundo sobre as características predominantes da cultura tecnológica contemporânea, articulada e modulada pelos media eletrônicos - reflexão em que se insere o conjunto das considerações feitas no tópico anterior e a partir da qual se poderá melhor vislumbrálas. Na sequiência, retornar-se-á à questão da condição da arte.

\section{Estética, mercadoria e cultura}

A fase social-histórica anterior à difusão do fetichismo estético da hiper-realidade corresponde à estética da mercadoria, conceito cunhado por Wolfgang Fritz Haug (1997) para explicar o surto de estetização do valor de troca e da mais-valia, socialmente pressuposta na ampla promoção publicitária daquele. A fase contemporânea que, nesse aspecto, se vivencia corresponde, mais além, à es-

social, a massa; mais real que o real, o hiper-real; mais verdadeiro que o verdadeiro, o modelo e a simulação; mais pleno que o pleno, a obesidade e a saturação; mais móvel que o movimento, a velocidade e a aceleração; mais sexual que o sexo, o pornô; mais visível que o visível, a obscenidade ( $p$. 11); mais funcional que o funcional, mais final que o final, a hipertelia (p. 12). Nessa espiral de redobramento, nessa escalada excrescente, nessa supermultiplicação vertiginosa dos atributos formais, encontra-se, segundo Baudrillard, a figura do êxtase, a qualidade própria de todo corpo que gira em torno de si mesmo até perder o sentido e que, por isso, resplandece em sua forma pura e vazia ( $p$. 9-10). Assim, a moda é o êxtase do belo, a simulação é o êxtase do real, a massa é o êxtase do social, a antipedagogia é a forma extática, isto é, pura e vazia, da pedagogia, e assim por diante.

10. O que testemunharam, no entanto, permanece, obviamente, válido, uma vez que, no plano da prática, o processo foi menos superado que aprofundado. A categoria da superação implica, nesse âmbito, a lógica de realização completa do processo, não o processo, ele mesmo, em sua continuidade transversal. 
tética da cultura, ${ }^{11}$ conceito cujo conteúdo absorve e, ao mesmo tempo, transcende o diâmetro da significação teórica do conceito de estética da mercadoria. Poder-se-ia aventar que, se absolutamente tudo quanto existe na vida regida pelo capital se converteu em mercadoria, então tematizar a fase contemporânea desta referir-se-ia, por si só, direta e exclusivamente, à própria cultura, em sua poíesis, estrutura e totalidade, em clara alusão de que a estética da cultura equivaleria, no fundo, à estética da mercadoria, de modo que não haveria motivo para diferenciá-las e, mais ainda, para problematizar o assunto. $\mathrm{O}$ argumento seria promissor não fosse equivocado. Seu referendo, sem mais, opera uma confusão entre os dois tipos relativamente bem demarcados de estética e de estetização. A estética da cultura, nos termos propostos no presente ensaio, é uma extensão assaz transformada da estetização da mercadoria. Várias mediações estruturais complexas podem ser observadas entre uma e outra, como, por exemplo, o enorme desenvolvimento e sofisticação das tecnologias em geral, a colonização empresarial e institucional acelerada das redes comunicacionais, a circularidade social em excesso das imagens artificiais e a formação do sistema mediático, tecnouniverso invisivelmente extensivo que simula e, simultaneamente, toma o lugar do que até pouco tempo se conhecia como sistema social, nos termos assentados pela ensaística sociológica, filosófica e econômica dos séculos XIX e XX (Trivinho, 1998, p. 47-54). Tais vetores de mediação, por poucos que aqui se indiquem, provocaram uma radicalização acentuada da tendência inaugurada pela estética da mercadoria. O horizonte culminante desse processo é o fenômeno da estética da cultura, tal como hoje consta abertamente realizado. ${ }^{12}$

11. O termo cultura, constitutivo dessa expressāo conceitual, é tomado, no presente ensaio, na acepçāo mais antropológica que sociológica, a saber, como uma macroconfiguração social-histórica dinâmica, sujeita a transmissão hereditária (sincrônica e diacrônica) permanente, inscrita tanto no âmbito simbólico/imaginário, quanto na esfera da materialidade/objetalidade da existência - guardando, pois, sinonimia com o conceito de sociedade -, e que, como tal, abarca a totalidade das criações humanas (sejam elas de que natureza for), dotadas de significação arbitrária e definida no tempo e no espaço (idéias e valores, relações e processos, comportamentos e práticas, objetos etc.).

Sobre a especificidade do conceito de estética, veja-se, em especial, o próximo subtópico.

12. A estética da mercadoria, não obstante ter sido Haug (1997) o criador do concelto, pode prescindir legitimamente de ser analisada a partir do ponto de vista econômico marxista ortodoxo - como o fez Haug. Integrada ao universo da estética da cultura, a estética da mercadoria permite ser vista através do mesmo 
Não se trata, pois, de um neologismo conceitual para nomear e cartografar o dejà-vu - na forma dos mesmos processos, objetos e tendências - no contexto da criação conceitual. A estética da cultura corresponde à lógica de uma época inteiramente outra, posto que, envolvendo elementos que não se apresentam plenamente na estética no plano das mercadorias, abrange universo de dados diverso e implica uma atmosfera de desenvolvimento da subjetividade, da socialização e das práticas distinta da das fases pregressas do capitalismo.

\section{Estética: acepção do termo}

A estética da cultura é um fenômeno técnico extremamente avançado, no sentido mais amplo, vale dizer, um "construto" somente viabilizado em determinadas condições tecnológicas, por pressuposto tardocapitalistas. Ela jamais poderia ter uma proliferação tão veloz não estivesse ancorada na profusão complexa das técnicas e na sofisticação eletrônico-informática das maquinarias. ${ }^{13}$ Nisso reside o seu melhor sentido de tecnoestética ou estética da cultura tecnológica ou estética do capital em sua fase presente, global, indeterminada, espectral, pós-moderna.

Essa estética não pertence à cultura contemporânea mundializada; mais que tudo, ela a é - nomeadamente, a forma peculiar e predominante de autoposição histórica dessa cultura. Trata-se de um construto que joga com os modelos, a linguagem publicitária, as imagens tecnológicas, a lógica do espetáculo e do sensacionalismo, os desempenhos performáticos e a simulação (cf. Baudrillard, 1981, p. 12 e ss; e 1976, p. 110-117) (sobretudo mediática) do real. Como tal, consiste numa espécie de imperativo para todas as ações e decisões, em quaisquer âmbitos, uma matriz em que vem se precipitar o conjunto da vida na sociedade contemporânea.

prisma que se pode ver aquela. Para tal reescalonamento teórico-epistemológico (aí compreendidas as rupturas necessárias, das menores às maiores), o pósestruturalismo e o pós-modernismo do último quartel do século $X X$ fornecem, suficientemente, um quadro de inspiração apropriado, mormente no que concerne à tese do primado dos significantes na cultura, ao qual se faz referência na seqüência da argumentaçẫo.

13. É esse vínculo de base, direto e inextricável, que determina, aliás, a sua existência exclusivamente no plano do significante, como fenômeno de superfícies, conforme assinalado adiante. 
Não se trata, pois, de uma estética como disciplina teórica, como um saber orientado para o estudo do belo, das produções artísticas do espírito ou da arte em si. Igualmente, não se trata do impacto da arte sobre os sentidos. A rigor, essa estética não possui ligação com o que em geral se entendia pelo termo na Antigüidade Clássica e na alta Modernidade. Ao contrário, ela significa a ruptura total com a estética legada pela tradição. Enquanto a arte constava apartada do universo da vida cotidiana - para expressá-lo nos termos da Escola de Frankfurt -, sujeitos do conhecimento puderam fundar a estética como sistema teórico, com domínio sobre um recorte do mundo. Contudo, quando a arte se incorpora à produção de mercadorias e, já a partir daí, mistura-se à vida comum, e quando, mais ainda, a sua produção se confunde com a produção da própria realidade, alterando a natureza e a lógica desta, tornando-a hiper-real, então é a tecnologia e suas necessidades intrínsecas que passam a urdir uma estética própria, agora não num recorte minoritário do mundo, mas no mundo em sua extensão mais ampla: ${ }^{14}$ outdoors de todos os tipos (dos impressos aos eletrônicos), neons, logotipos e fachadas de estabelecimentos comerciais; placas de logradouros, signalética do sistema de trânsito; muros e paredões públicos grafitados, mesmo pichados (no sentido reversivo a todos os exemplos doravante citados) ${ }^{15}$; cartazes; programação radiofônica e televisiva, projeto gráfico de periódicos, dados informáticos (de toda espécie); ambiências internas (do automóvel ao domo e ao local de trabalho, buscando-se sempre a assepsia); design e estampas de objetos [tomados em sentido genérico, ainda que (aqui) no

14. Diante de tal confisco efetuado pelo sistema de maquinarias, aos sujeitos do conhecimento - como a todos os entes humanos - não resta senão reconhecer, nesse aspecto, a sua própria condição intelectual no presente, desde as origens formativas desta até as suas reverberações. Obvio, portanto, que o que aí se produz já não pode ser catalogado dentro dos quadros da estética como disciplina, cuja produçāo - enfatize-se - era prerrogativa de entes humanos. O problema implica, com efeito, um fazer teórico e uma teoria, certamente - e, sem dúvida, uma teoria da cultura global -, mas, à diferença de outrora, eles incidem sobre a estética dessa cultura tecnológica, ou melhor, entranhada nela.

15.Do ponto de vista da estética da cultura tecnológica, não importa tanto, no limite - se bem que o assunto seja mais complexo que esta asseveração -, se tal intervenção urbana expressa contestação política orientada, indignação cultural difusa, desejo de obscenidade ou comportamento conservador (de que os grafites são geralmente acusados: reelaboração cultural sublimada, domesticação política da pichação). Em relação aos dois primeiros casos, lembre-se que todo e qualquer estado estético urbano, sobretudo se amplamente proliferado, traz consigo sua sombra crítica, por mais que, por ironia do contexto, essa sombra acabe, paradoxalmente, por se enquadrar no efeito de conjunto. 
âmbito da matéria-forma - sempre técnicos: das miniaturas aos megaprojetos arquitetônicos modernos e pós-modernos (incluído o paisagismo urbano), suntuosidades regadas a materiais concorrentes, por isso recicláveis]; personal look (moda à frente), e assim por diante. ${ }^{16}$

Da rudeza aleatória do estetismo citadino, díspar no conjunto, aos psicodelismos programados da indústria do áudio/visual e ao recorte narcísico mais irredutível, vale dizer, do espaço público ao corpo, todos os dados aí inscritos bebem na mesma fonte: a auto-referencialidade. Todos remetem, antes de mais nada, a si próprios - textualidade em miríade, boom da imagèrie, cromatismo infinito (da harmonia ao contraste), sonoridade non-stop (tonal, em sua totalidade), mixagens: puro fluxo de significantes linguísticos e/ou audiovisuais; numa expressão, pura visibilidade retórico-estética, retrato mais acabado do eterno féretro (sobretudo mediático) do referente/real. "A realidade foi expulsa da realidade", registra, com ironia, Baudrillard (1996 p. 26). Ao excesso dessa impressionante flora simbólica despolitizada, pródigo cenário de fronteira com a poluição anti-estética, corresponde o ensurdecedor mutismo de sua razão de ser - código segredado de conversibilidade interna absoluta que evoca, por conseguinte, a poluição ruidosa do nonsense, escala zerada do significado pela hiper-insistência dele mesmo. ${ }^{17}$

É assim que a estética da cultura tecnológica, intensa e paradoxalmente diversificada em sua manifestação por cumulação e superposição, em seu movimento de proliferação aparentemente unitário, em seu fio condutor processual (se é que, de fato, ela o possui), pode, por um lado, aparecer, profusamente, como um chamamento direto aos

16.Se a concatenaçăo desses fatores socioculturais, produzidos segundo interesses diversos e aleatoriamente arranjados no social, nada soa como arte, no sentido arbitrário e estrito do termo, suas reverberaçṍes provêm, ao menos, da execução dela, pelo miúdo, pontualmente, a partir de cada recorte de enlaçamento com o capital, o resultado, não por outro motivo, enquadrando-se, com justeza, na matriz da estética.

17. A transmissão radiofônica de uma partida de futebol é disso uma ilustração extrema: culto da velocidade, orgia do significante. Semelhante modus operandi pode ser reconhecido no clipe e no spot publicitário, no contexto televisivo. A celeridade irreversível do fluxo sonoro ou audiovisual do sinal de satélite - esse frenesi que hoje se confunde com as tendências predominantes da cultura mediática - lança (e restringe) violentamente a subjetividade à percepção (quase exclusiva) do significante, tornando vão qualquer desejo de retençăo mais duradoura do significado, o que não revela senão o status cultural secundarizado deste. 
sentidos (reclamando principalmente o olhar), ipsis literis (aesthesis), e, por outro, como um norteador e modulador dos mesmos - o que pressupõe, obviamente, que ela seja um norteador e modulador da atividade psíquica de todas as singularidades e da dinâmica de todos os processos sociais, revelando-se nisto, por conseguinte, o seu enraizamento histórico no modus operandi das sociedade tecnológicas contemporâneas. ${ }^{18}$

\section{Comunicação e estética}

A estética da cultura tecnológica resulta, a rigor, mais definidamente, da ampla colonização empresarial e institucional das redes comunicacionais a partir da Segunda Guerra Mundial. ${ }^{19}$ Por certo, não resulta de imediato, mas progressivamente, dentro dos limites das façanhas técnicas materializadas em cada década recente. ${ }^{20}$

A natureza das maquinarias implicadas na colonização das redes, a forma global pela qual essa colonização se efetivou (e continuará se efetivando) e as características dos produtos culturais dela dimanados demonstram, aliás, que o fenômeno comunicacional $e$

18.A taxa proposital de generalidade do argumento dá bem a noção do diâmetro espacial da estética da cultura tecnológica. Ela não se concentra em territórios geográficos específicos. Fenômeno mundial, apresenta-se tanto em países desenvolvidos, quanto subdesenvolvidos - aqui, as metrópoles e demais cidades grandes dos países do Terceiro Mundo; lá, o hemisfério norte do continente americano, a Europa ocidental e as metrópoles do bloco oriental que se estruturaram no pós-guerra conforme o estilo ocidental-capitalista). Com efeito, o desmoronamento das burocracias socialistas do Leste, a queda do muro de Berlim e a recomposição das relações de poder ao nível internacional em proveito da hegemonia econômica, cultural e militar norte-americana - com a conseqüente consolidação de um mercado global processada segundo os interesses desse pais - estão dilatando sobremaneira o referido diâmetro, bombeando a estética da cultura tecnológica para áreas geográficas que ela nunca havia antes adentrado.

Guardadas as proporções, concepção semelhante a respeito da proliferação estética foi desenvolvida por Arthur Kroker e David Cook (1988, p. 16 e seg.), pelo prisma de uma teoria pós-modernista, anarco-niilista, da cultura. Dissecando o contexto pós-moderno, os autores desvelam a subordinação de toda a existência à lógica do espetáculo, a TV jogando, nesse processo, um papel exponencial. Sem discordância de mérito, os elementos teóricos mobilizados no presente ensaio não somente especificam melhor, senão ainda reescalonam socialmente a temática mediante um quadro epistemológico distinto.

19. Para uma ampla contextualização da questão, veja-se Trivinho (1998, mormente p. 17-28).

20. Nunca é demais frisar que essa passagem - da fase em que a estética irrompe na cultura pelo campo das mercadorias à fase em que ela se alastra nas e através das redes e se confunde com toda a cultura - não tem data fixa; ocorre como transição que se estende por alguns anos, todos concentrados nas décadas de 50 e 60 do século passado. A partir de então, instaurou-se o excesso da estética. 
o fenômeno estético sempre estiveram juntos; antes de figurarem em paralelo, percorrem, abraçados, o mesmo caminho, em idêntica direção. ${ }^{21}$

Essa união se torna patente já pelo fato de as corporações da telecomunicação, responsáveis pela instituição e colonização das redes, terem, elas mesmas, cumprido, desde o início, no cenário social-histórico, a função de intermediar a promoção publicitária das mercadorias de indústrias multinacionais e outras grandes empresas - mercadorias para cuja constituição a arte, conforme anteriormente visto, já havia sido amplamente conclamada, sob os auspícios de máquinas de reprodução técnica e de técnicas de definição de design. Tal união se enuncia igualmente pelo eixo da produção e circulação das imagens tecnológicas. Sempre geradas por um tipo de medium, e neles fincadas, e formando ampla cadeia iconográfica (na qual a arte também se vê implicada), com alta taxa de reciclagem social, as imagens são, em conjunto com os modelos nelas embutidos, uma forma privilegiada de irradiação da estética da cultura tecnológica. A mencionada união se evidencia ainda mais quando todo o sistema mediático - e, com ele, a existência inteira dos próprios entes humanos - acaba por se espelhar na estética que ele mesmo contribuiu para disseminar através das redes. Tal é o momento em que a comunicação se enreda na lógica igualmente auto-referencial da publicidade. Por essa via, os media (pense-se prioritariamente na TV e, mais recentemente, no cyberspace), cerrados em si mesmos e não se arejando senão para seus próprios pares, não se referem a uma realidade que lhes é exterior - até porque, evocando Baudrillard, essa realidade se desfigurou por auto-inflação estética, cedendo lugar ao hiper-real ${ }^{22}$-; antes, forjam uma "realidade" para si próprios (a qual estendem, totalitariamente, para o mundo inteiro) e, em função dos parâmetros nela embutidos, organizam suas atividades e produções, seus produtos não reforçando outra coisa senão, obviamente, tal "realidade". Deixando de ser representacionais - vale enfatizar,

21. Pressupostamente, a comunicação e a estética, visto que implicadas nas redes, presidem o advento histórico e o enraizamento sociocultural da pós-modernidade (cf. Trivinho, 2001, p. 39-78).

22. De qualquer forma, se tal realidade ainda estivesse em voga, dar-se-ia justamente o contrário, posto que ela, como referente, é que sempre seria convocada para dentro dos media, a fim de neles encontrar a sua espetacular desintegração. 
não representando mais nada do mundo, antes sendo eles mesmos o próprio mundo -, convertem-se também em significantes puros que mais não fazem do que remeter, tautologicamente, a si mesmos. ${ }^{23}$ Esse processo revela um esvaziamento do que se poderia chamar, em sentido figurado, de densidade simbólica, complexa riqueza do signo que doravante se nutre do vácuo do caráter representacional dos media em relação ao mundo circundante. Nisso radica a união antes mencionada: pelo fato de os media operarem em circularidade viciosa, auto-referencial e ad infinitum - numa palavra, no vazio -, por condicionarem a liberação de significantes (aqui entendidos como signos congelados, amputados de qualquer profundidade de campo e de sentido) e se reduzirem a ela, é que a comunicação, em seu conjunto, se converte num fenômeno estético, nos termos em que a aesthesis é tomada no presente ensaio. ${ }^{24}$ Eis que a estética da cultura tecnológica não apresenta nenhuma "densidade", nenhuma verticalidade sígnica, vigorando, antes, como macrofenômeno de superfície, restrito aos significantes.

\section{Forma estética do valor - flutuação do capital}

A alta sofisticação fetichista do social contemporâneo, expressa na estetização generalizada como processo tecnológicocivilizatório, implica, diretamente, um tema por demais clássico da teoria social e econômica: a questão do valor. Dado que a reflexão deve fazer aqui o seu devido estágio, abra-se, pois, um parênteses na rota teórica do presente estudo, a fim de aprumar um sucinto aprofundamento sobre o assunto.

Sabe-se que, na teoria econômica de Marx (1983, p. 45 e seg.), a mercadoria possui dois valores imanentes: o valor de uso e o valor propriamente dito. O valor de troca é, por sua vez, a forma que

23. Sobre o caráter estruturalmente pleonástico da comunicação e, por extensão, do sistema mediático, veja-se Sfez (1994, especialmente, p. 13-16, 69-104 e 128-242, nas quais o autor concentra a sua explanação sobre o conceito de tautismo, neologismo formado para nomear o plasma de sentido correspondente à aglutinação inextricável dos termos tautologia, autismo e totalitarismo).

24. Reside nesse acontecimento o que, segundo Baudrillard, responde justamente pela provocação da maior sedução contemporânea: o ver involuntariamente (o) nada onde se vê (e se crê que se vê) algo. Não por outro motivo, Baudrillard (1996, p. 24), em implícita menção à conhecida reflexão de Heidegger sobre a 
o valor assume no modo de produção capitalista. ${ }^{25} \mathrm{~A}$ mercadoria aparece, pois, em duplicidade: valor de uso e valor de troca (ibid. p. 49). ${ }^{26}$ Pouco mais de um século depois de lançado o primeiro volume de $O$ Capital, o desenvolvimento industrial e pós-industrial acelerado acabou, com efeito, por implodir essa estruturação dos valores integrantes da mercadoria, modificando a própria natureza do valor. Num primeiro momento, esse desenvolvimento provocou uma subordinação do valor de uso ao valor de troca. Na sequiência, liquidou o valor de uso e conferiu onipotência ao valor de troca. De certa forma, esta ainda é a sua fase atual, a lógica do valor generalizada para todas as áreas.

Essa concepção encontrou o seu momento áureo de banalização logo após a Segunda Guerra Mundial. A crítica social ao existente segundo a qual as produções, fossem elas quais fossem inclusive as relacionadas a processos e produtos sociais mais abstratos, como o saber, a educação e a sexualidade, regiam-se, ipsis literis, pela lei do valor havia sido, por essa época, neutralizada pela vultuosidade dos próprios fatos que lhe serviam de fundamentação empírica. Mesmo esse reconhecimento de ocaso não foge a tal regra, tanto mais quando se faz órfão de acréscimos argumentativos que lhe minorem a defasagem.

A única forma de superação desse anacronismo, com saldo favorável em termos de atualização da reflexão teórica, é a

metafísica, registra: "A grande questão filosófica era: 'Porque é que há alguma coisa em vez de nada?' Hoje, a verdadeira questão é: 'Porque é que há nada em vez de alguma coisa?'". (Precisamente 60 anos antes da notação de Baudrillard, Heidegger assim abria o seu Introdução à metafísica (1978, p. 33), texto de uma preleção feita em 1935 na Alemanha: "Por que há simplesmente o ente e não antes o Nada? Eis a questão."

O ver nada em algo - expressāo que é bem diversa da acima comentada, a presença do nada em detrimento de algo -: é o caso típico da produção cultural televisiva. O sujeito é seduzido pela imagèrie justamente porque ela não tem, no fundo, nenhum sentido. O desejo do nada se expressa, de forma surda, na sedução pelo espetáculo do vazio, que é, vis-à-vis, a sedução pelo vazio de si próprio (cf. Baudrillard, 1987, p. 134-145).

25. Diz Marx: "Os valores de uso constituem o conteúdo material da riqueza, qualquer que seja a forma social desta. $\mathrm{Na}$ forma de sociedade a ser por nós examinada [a capitalista], eles constituem, ao mesmo tempo, os portadores materiais do - valor de troca" (ibid., p. 46). O valor de troca é "a maneira necessária de expressão ou forma de manifestação do valor, o qual deve ser... considerado independentemente dessa forma" (ibid., p. 47).

26. Ressalte-se, aliás, que, nos termos de Marx (ibid., p. 53), "elas são só mercadorias devido à sua duplicidade, objetos de uso e simultaneamente portadores de valor. Elas aparecem como mercadorias ou possuem a forma de mercadoria apenas na medida em que possuem forma dupla, forma natural e forma de valor". 
mobilização desta em direção à indagação - tão fundamental quanto premente - acerca da hodierna (a rigor, desde um passado recente) natureza contemporânea do valor. Traçam-se, a seguir, os principais delineamentos a respeito.

É patente que o desenvolvimento tecnológico, de par com a política que sempre o favoreceu, arrancou a lei do valor de seu cativeiro setorial, presa a objetos e serviços concretos, e a lançou a amplos horizontes, por assim dizer, estruturais e identitários a exteriorizações imateriais. Todavia, no transcurso das décadas, no compasso da incorporação da arte ao processo de produção, o valor foi como que - numa metáfora - mudando de pele e de escala: foi se tornando estético. Reconfigurando, pois, os argumentos lançados acima, esta é a fase mais atual do valor, a forma em que hoje ele se apresenta.

Obviamente, não se trata de um valor que substitui o valor de troca. Ao contrário, caminha fundido a ele e o estimula. Portanto, um objeto, quanto ao seu valor, precisa ser, atualmente, melhor qualificado: ele não possui um valor atrativo apenas econômico, expresso no valor de troca; possui, antes, um valor atrativo que transcende esse aspecto, valor que somente se produz amparado na estética e, por óbvio, se destina à troca comercial, a cujas leis, de todo modo, permanece estritamente subordinado. Em termos prosaicos, para todos os efeitos analíticos, qualquer objeto possui, desde há décadas, um valor estético e um valor de troca. ${ }^{27}$

Notem-se aí, porém, com ênfase, certas peculiaridades. Em primeiro lugar, o valor estético não é um recurso meramente agregado ao valor (e, por extensão, ao valor de troca); é, antes, o

27. Duas vias que estão pressupostas na concepção teórica de Haug (1997), vale especificar: a de que, nas últimas décadas, a estética assumiu existência separada do corpo da mercadoria e a de que, nesta, só existiriam, a rigor, esses dois valores, o valor estético e o valor de troca. Com relação a essa última idéia, devese ressalvar que Haug não utiliza o conceito de valor estético, posto que, para ele, a estética não se constitui como valor, mas como simples aparência ou abstração que, servindo como embalagem sempre renovável da mercadoria e funcionando nesta como (segunda) superfície atrativa, seduz os consumidores, convidando-os a realizar o valor de troca. Acrescente-se ainda que, segundo Haug, a produção contínua e renovada de aparências ou abstrações estéticas desordena, por conseguinte, o valor de uso, eliminando a sua concreção e transformando-o também em mera aparência ou pura abstração. Como tăl, ele não se extingue; encoberto, camuflado, perdura com o máximo de potencial atrativo em relação a desejos e aspiraçōes individuais.

Reafirmem-se aqui, todavia, os comentários feitos na nota 12, uma vez que ao 
próprio valor, já em sua gestação e em sua nascença. Isso se evidencia, por óbvio, em função de o valor estético representar a arte como vórtice de geração de valor desde quando ela (arte) consta imanentemente interiorizada no processo de produção. $O$ fenômeno não equivale, pois, a algo assim como uma arte de tipo comercial, na qual economia e estética conservam-se em paralelidade cooperativa, numa situação de exterioridade mútua a priori, à semelhança de uma mistura heterogênea, o trabalho estético vigorando como componente associado ao trabalho principal, responsável exclusivo pela produção, a arte funcionando apenas como (instrumento de) adorno do resultado mercantil. $O$ valor estético significa algo mais profundo: equivale à arte fagocitada e hipostasiada como valor, embutida, como tal, nas entranhas da elaboração de seja qual for o objeto ou serviço - o que se traduz num princípio peremptório: na atualidade, ou o valor é estético ou não o é. Esse apontamento tem, em segundo lugar, a propriedade de realçar outra importante nuança. Se, na teoria econômica de Marx, o valor de troca corresponde, na modernidade, à forma do valor, na era da estética da cultura tecnológica o valor estético faz predominantemente as vezes daquele (de troca), com a peculiaridade de, sendo a viga referencial do valor (mais do que a sua mera forma), não toldar o valor de troca, nem destruir totalmente a relação deste para com o valor, e, vis-à-vis, para enfatizar, de preservá-los e operar junto com eles. A existência do valor estético patenteia, por si mesma, um rastro de sobredeterminação em cadeia. Em terceiro lugar, o valor estético corresponde a um momento social-histórico em que o valor não tem mais medidas e em que o valor de troca não possui mais referências lógicas e reais. Quando o valor se faz estético, o capital entra em sua fase de flutuação e, tempos depois, via redes comunicacionais, espectraliza-se por completo (Trivinho, 1998, especialmente p. 37-45).

tema é imperioso imprimir direcionamento teórico distinto do de Haug, que preferiu estudar a questão estética à luz das estruturas d'O capital, de Marx, metodologia teórica sem mais adequação às condições estruturais e conjunturais da sociedade tecnológica, em que já não é mais possivel falar em determinações estritamente econômicas e em que (aliás, justamente porque) estas comparecem amplamente subordinadas à lógica da cultura, agora representada pelo imperativo e pelos fluxos do código mediático mundial - e não esta subordinada àquelas, conforme a clássica e igualmente polêmica premissa marxista. No mais, atentese para a seqüência adversativa da argumentação. 
Nesse ponto, os argumentos retroagem e se refundem. Se a primeira aparição social organizada do valor estético se realiza, literalmente, no reino das mercadorias, com respaldo na incorporação da arte ao processo de produção, e se, a partir daí, ele já se espalha para todos os setores sociais, deve-se lembrar, com efeito, que, nessa passagem, o valor estético, por se adensar e, bem assim, se saturar, sofre também grande mutação. Essa observação denota - sob todos os riscos de um argumento por demais esquemático - que $o$ valor estético que sustenta a estética da mercadoria não é de todo semelhante àquele que sustenta a estética da cultura tecnológica. Enquanto o primeiro se prende, a rigor, diretamente, ao objeto ou serviço mercantil e permanece no círculo de sua gravitação, o segundo, por sua insoldável abstração, espectralidade e imensurável difusão, prescinde dessa atrelagem. Liberado da materialidade da mercadoria, o valor estético que subjaz ao fetichismo estético integral pode circular melhor como fluxo. Pressuposto nas imagens artificiais de todas as telas, bem como nos modelos, nas simulações, nas performances e na autopromoção publicitária de todas as coisas (existentes e não-existentes), ele pode, de fato, provocar melhor efeitos de vertigem.

Para acusar essa sutil dissimilitude numa linguagem desusada - já que o tema é clássico -, se, por um lado, o valor de troca equivale à forma do valor correspondente à lógica moderna do modo de produção capitalista, por outro, o valor estético funciona como o tipo de valor correspondente à lógica pós-moderna do modo de produção tardocapitalista. ${ }^{28}$ Se esse último modus operandi diz respeito, primeiro, à flutuação e, depois, à espectralização do capital, isso não se deve senão, propriamente, à força paramétrica do valor estético e de sua intensa irradiação e enraizamento no âmbito das relações sociais. A título de melhor dissecação da proposição, saliente-se: até enquanto a manifestação do valor estético é menos socialmente acentuada, sua reverberação econômicocultural é a flutuação do capital; sua expressão pantópica funda, por sua vez, a espectralização não somente deste, mas também de todo o capitalismo como formação social. ${ }^{29}$ A flutuação

28. Por inspiração em Jameson (1997, especialmente p. 27-79), em cotejo crítico com Mandel (1985).

29. Essa problemática foi apreendida por Debord (1971, p. 22), há pouco mais de 
está para a estética da mercadoria, assim como a espectralização está para a estética da cultura tecnológica, com a ressalva de que, no âmbito dessa última, a flutuação, ao contrário de ser relativizada ou abolida, apresenta-se infinitamente radicalizada.

Se, no começo da segunda metade do século passado, já nada mais existia sem que permanecesse (e mesmo tivesse nascido) subordinado à tutela do valor de troca, na atualidade, deve-se, com efeito, refazer o argumento: nada do que existe ou se processa no mundo deixa de reger-se, de alguma forma, pelo imperativo estético, pelo código significante institucionalizado.

\section{III - Horizonte negativo da arte}

"A ausência das coisas a si próprias, o facto de não terem lugar tendo
ar disso, o facto de tudo se retirar sob a sua própria aparência e não
ser nunca idêntico a si mesmo: tal é a ilusão material do mundo." Jean Baudrillard (1996, p. 24)

Após o reescalonamento teórico e a recontextualização temática anteriormente cumpridas, retome-se, pois, a questão da condição da arte, para reavaliá-la no quadro epistemológico do presente ensaio e para encerrar o arco da discussão.

\section{Comprometimento do caráter representacional da arte - neutralização pela liquidação" do potencial simbólico}

No início dos anos 40 do século passado, Benjamin (1978, p. 212 e seg.) demostrou que a obra de arte, ao ser tecnicamente reproduzida em série, resta despojada de sua aura, isto é, do fator histórico que lhe garante a unicidade no espaço e no tempo e, portanto, a autenticidade e autoridade como fundação original. No contexto do presente ensaio, importa ressaltar, mais fundamente, que a arte, ao ser diretamente incorporada ao processo de produção, despoja-se de seu caráter representacional. Esta expressão conceitual

três décadas, num quadro epistemológico inteiramente distinto, com ênfase na categoria do espetáculo: "Le spectacle est le capital à un tel degré d'accumulation qu'il devient image". Do mesmo autor, veja-se também Commentaires sur la société du spectacle (1988). 
não abrange uma função sociocultural que se esgota na lógica operativa de um espelho: refletir fielmente o real - lema que foi o do realismo na esfera da pintura, ancorado em técnicas perspectivísticas do espaço formalizadas no Renascimento italiano; e que ainda é o da fotografia, especificamente nos casos em que seus usos sociais (seja, por exemplo, no âmbito do jornalismo ou do aparelho policial, seja no universo das práticas familiares) se norteiam, no que tange à relação com a época e com a categoria do controle, exclusivamente por objetivos de registro cotidiano, de documentação, de geração de memória. A expressão conceitual em questão implica, antes, uma função representativa em geral, na direção de um desvelar algo sobre o real, de certa maneira e a partir de certa visão ou sensação de mundo. Num afresco de tipo tradicional, por exemplo, as figurações apresentadas mantêm com o real um certo distanciamento; ipsis literis, podem, por isso, evocá-lo. Com a proposição de sua temática, com suas combinações e tons cromáticos, com a perspectiva a partir da qual as figuras e/ou cenários são aludidos, com sua relação com o espaço, com o tempo, com a(s) técnica(s), com o suporte e suas limitações, enfim, com suas possibilidades e constrangimentos, um quadro fala ou faz falar, obviamente, o real social-histórico que o enreda e o constitui, ou contém, no mínimo, um conjunto de indícios que levam a repensar esse real, ao mesmo tempo que, mais prosaicamente, fornece inúmeras informações sobre as condições psicoemocionais do artista durante o processo de criação e sobre os procedimentos estéticos e a natureza dos materiais empregados para a consecução da obra.

Fenomenologia inteiramente diversa ocorre no caso da arte incorporada ao processo de produção - para ficar apenas nesse recorte temático, a fim de elucidar a questão. Nesse plano, a arte, como elemento imanentemente constitutivo do valor e otimizador do valor de troca, coincide com a mercadoria (e, por pressuposto, com o processo de sua elaboração, com a sua forma e com a sua significação). Criações artísticas que torneiam ou adornam objetos mercantis, seja pelo design, seja pelo rótulo, ou que promovam socialmente tais objetos por meio de recursos publicitários variados (impositivos, em si e por si, como a própria mercadoria promovida, e ainda sob a égide desta, tomada, aliás, como álibi instrumental) - o que não deixa de ser uma prática de adornamento do valor de troca, no sentido amplamente ex- 
tensivo dessa prática, identitário aos media - não mantêm com o real nenhuma relação de distanciamento. ${ }^{30} \mathrm{~A}$ materialização desse tipo de trabalho estético é o real. ${ }^{31}$ Tais criações não podem, portanto, evocálo, no rigor do esquema operatório subjacente a tal verbo; podem, tão-somente, atualizá-lo, revelar o seu momento, o seu estágio no quadro geral de sua própria saturação estética) - o seu "estado da arte", por assim dizer. ${ }^{32}$ Dito por outro ângulo, em todas as suas modalidades de existência e com suas soluções técnicas, modelares e cromáticas, a arte integralizada à forma mercadoria ou a ela vinculada, direta ou indiretamente, nada "fala" sobre o real environmental, algo assim como se com ele guardasse relação de exterioridade; ao contrário e antes de tudo, ela $e ́$ - ressalte-se - esse real que a todos permeia, constitui e enreda. Certamente, a arte provê, no caso, a todo instante, indícios que levam a (re)pensar o real. Não obstante, ela o faz a partir de sua condição peculiar, nomeadamente, na função de algo interno a esse próprio "real estético". ${ }^{33}$

Com o comprometimento de seu caráter representacional, a arte - ainda no mesmo plano de abordagem - se despe igualmente de seu potencial simbólico. A neutralização desse potencial culmina em completo autismo: a arte acaba por referir-se e remeter a si mesma como se fosse "o" referente e por autopromover-se como algo absoluto. Incorporada ao reino da mercadoria, ela se transforma num signo vazio - um significante. ${ }^{34}$

30. A necessidade analítica do emprego do termo "real" neste e nos próximos quatro subtópicos não deve causar dissuasão a respeito do traço predominante - já nomeado - do contexto social-histórico presente, traço que tanto reescalona imanentemente o sentido do mencionado termo, quanto norteia o tratamento teórico do estado do objeto em questão, a arte: não se trata mais do referente/real convencional, mas de um "construto" com outro estatuto, que transcende a acepção que the oferece a cláusula terminológica do real e, por isso, vê-se melhor abrangido pelo conceito de hiper-real, de Baudrillard, nos termos anteriormente indicados.

31. Frise-se: nem parte dele faz; é-o.

32. Se é que a metáfora, muito apropriada ao contexto, não prejudica, todavia, a compreensão da tendência da argumentação.

33. Donde o mencionado (re)pensar se põe como um (re)elaborar o environment tecnossígnico a partir de seus próprios ingredientes constitutivos, vale dizer, a partir de suas próprias entranhas, e isto com o necessário concurso da categoria da crítica, perfeitamente possível na relação de imanência dinâmica entre sujeito e objeto (se é que tais vetores ainda se põem assim, quer dizer, exteriores um ao outro, mesmo no âmbito da linguagem).

34. Convalidando-se o exposto na nota 24, tal é, aliás, segundo Baudrillard (1997, p. 154), o aspecto igualmente mais relevante em matéria de estética: "O acontecimento fundamental da arte consuma-se quando o Nada aflora nos signos, 
Tal esvaziamento encontra correlato - para mudar de registro - no caso da reprodução em série da obra de arte por meios tecnológicos.

Em ambos os recortes, o fenômeno pode ser percebido já no próprio processo de incorporação ou de reprodução. Enquanto, porém, neste último - para evocar os termos de Benjamin -, o esvaziamento se apresenta como abolição da aura, no primeiro processo, evidencia-se como "liquidação" do simbólico. ${ }^{35}$

\section{Corrosão da razão de existência da arte}

Para além do exposto, entretanto, se a arte for encarada pelo prisma de sua significação social-histórica mais convencional, a saber, como prática-instituição de que resulta a produção de unicidades e autenticidades plenas de potencial simbólico, deve-se apontar outro esvaziamento, de caráter mais genérico, só perceptível e acessível ao conceito a partir de um mapa de conjunto: diz respeito à corrosão da razão de existência da própria arte. Trata-se de um esvaziamento gestado e formalizado no âmbito social-histórico pelo acentuado "estressamento" industrial e pós-industrial dos dois processos mencionados - a integralização da arte na produção e a sua reprodução em série pela tecnologia -, bem como, por extensão, pela extrema saturação dos resultados socioestéticos desses processos, em todo o universo urbano, mormente no âmbito do domo (desde que ele foi transformado em rentável mercado). Tal esvaziamento não é, deles, senão um epifenômeno identitário, um efeito colateral por potencialização.

quando o Vazio emerge no coração do sistema de signos."

Lembre-se, entretanto, que tal proeza - que, no limite, ecoa a nadificação da cultura - foi melhor efetivada sob o domínio do mercado mundializado a partir do final da década de 40 do século passado, o que não atesta senão o ímpeto a uma só vez criativamente destrutivo e destrutivamente criador do capital (industrial e pós-industrial): em seu movimento histórico (mais aleatório que planejado ou, antes, mais aleatório porque plajejado), o capital desempenha ruidosamente a política de terra arrasada do que existe para moldar para sempre o mundo à sua imagem (o que Marx, aliás, já havia dito), a saber: o deserto, gélido cenário resultante da fluidez máxima de todos os signos e valores, a fim de que as coisas restem, no fundamental, preservadas.

35. O termo liquidação comparece entre aspas para chamar a atenção para o seu duplo sentido, ambos verdadeiros: como aniquilamento e como vendição a preço de ninharia, linguagem de negócios tão apropriada ao contexto em questão. 
É certo que, já no excesso de mercadorias estetizadas, bem como no excesso de reproduções tecnológicas, a arte encontrou o seu momento de relativização, de neutralização, de anulação. No contexto abordado, não existe processo de incorporação e de reprodução que deixe de se apresentar, ao mesmo tempo, como processo de descredenciamento programado do objeto dessa incorporação e reprodução. No cômputo geral, é como se, nessa medida, a arte fosse questionada na base, a partir do que ela passa, então, a agonizar como ato instituinte singular e autêntico; é como se por similaridade - se estivesse diante de um desaparecimento obtuso e sinistro, por arruinação quase total da eficácia estética. ${ }^{36}$

Entretanto, ressalve-se, com ênfase, que é somente com o advento, propagação e aprofundamento social da estética da cultura tecnológica - nos termos anteriormente especificados - a partir desses processos que tal pulverização e neutralização encontram a sua máxima definição. Em outras palavras, o esvaziamento geral da arte só se patenteia inteiramente quando essa estética tecnológica - feixe fetichista de significantes -, alastrando-se e freqüentando toda e qualquer produção, passa a indexar os processos e entes em geral do mundo, em seja qual área for. ${ }^{37}$

\section{Arruinamento da dimensão simbólica da cultura}

Tais alinhavos teóricos sinalizam para um acontecimento ainda mais significativo - óbvio, em certo sentido, mas nem por isso menos sutil -, apreensível por uma equação dedutiva: se a arte, mercadologicamente plasmada ao existente, vige na base da constituição da estética proliferada, então esta implica, mais que a mencionada decomposição do potencial simbólico, o arruinamento da dimensão simbólica da própria cultura como um todo. Estética da cultura tecnológica: estética auto-referencial, sígnica, da cultura desprovida dessa atmosfera crucial de significação, o simbóli-

36. Ao último trecho da assertiva deve-se necessariamente aditar que nem todo elemento enquadrado na cláusula da eficácia ou eficiência estética esgota-se, de fato - como sabido -, no âmbito exclusivo da estética (o qual, tanto mais hoje, converteu-se em absurdo). Não raro, os artistas sempre buscaram a eficácia estética como via de afirmaçăo de outro tipo de eficácia (política, moral, cultural, econômica etc.).

37. A temática será retomada no subtópico 5 , mais adiante.

$\overline{\text { Significação } 16 \cdot 174}$ 
co; vale dizer, tecnoestética da cultura perpassada por imaginários artificiais, por modelos em série, pelos fluxos publicitários autoreferenciais, pelo imperativo performático - uma cultura da simulação sígnica do real, tão intensa e docemente violenta em sua reiteração diuturna que - conforme visto - toma o lugar dele, o substitui e, a partir daí, propala o código de seu modus operandi: não a praxe da remissão simbólica, que cava, com folga, a flexibilidade, a volatilidade e a complexidade de qualquer cultura, mas o deslizamento previsível e ad infinitum numa cadeia socialmente circular de significantes, a qual só se realiza na superfície, no tecido das aparências, e ao calor da maior velocidade possível (a do tempo real), sob a chancela da gentil indiferença das massas. ${ }^{38}$

Com efeito, e não tanto paradoxalmente, as mesmas reverberações socioculturais apontadas validam-se, em retroação, para a própria estética da cultura tecnológica. Se ela é a plenificação urbanitário-tardocapitalista da produção artística em larga escala e se a plenificação de algo é, a rigor, sintoma de sua própria decadência, então (é possível conjeturar que) a estética da cultura tecnológica, de par com a arte, depara-se também - já nem tão depois de ter-se dado à luz, idiossincrasia do tempo histórico devida à aceleração factual de uma era automatizada - com o ocaso da razão de sua própria existência.

\section{Exaustão do projeto teórico da modernidade estética e das vanguardas artísticas}

O fetichismo estético integral e sua sombra contínua e inelidível, o esvaziamento da arte, comprometem, na base - como não poderia deixar de ser -, por sua vez, todo o projeto teórico da modernidade estética: também ele, em cadeia, se nulifica. Para registrá-lo à maneira sinóptica e a traços ilustrativos, com relevo para a Escola de Frankfurt: ${ }^{39}$ exaure-se o propósito de Adorno, embu-

38. Trata-se de condição social-histórica que, por ser irreversivel, costuma tripudiar diante dos sistemas epistemológicos tradicionais e modernos, rendendo risos sobretudo a quem, com eles, pretende abordá-la, sem, por isso, conseguir desvencilhar-se das malhas da melancolia política.

39. Por motivos (que o próprio texto, por si, revela) óbvios. 
tido na concepção teórica da arte como possibilidade de restauração genuína da transcendência olvidada. Extenua-se também o desejo de Marcuse, instilado no conceito de arte como recusa ou negação integral do totalitarismo cultural da sociedade unidimensional. Definha-se, ainda, em certa medida, a tenção de Jürgen Habermas, pressuposta na visão segundo a qual o domínio da arte permite recuperar o que se encontra ameaçado pela tendência desastrosa da modernidade e pela cultura pós-moderna.

A estetização generalizada e sua sombra perfazem, igualmente, as condições sociotécnicas estruturais que estão na origem do esgotamento dos movimentos artísticos modernistas e pós-modernistas de vanguarda, em especial observado no último quarto do século XX, com prolongamento até os dias atuais. A esse respeito, vale assentar, en passant, um comentário. Tal marcescência, depositária da morte do sujeito e da obstrução das possibilidades de transformação revolucionária da sociedade pela flexibilidade do sistema industrial e pósindustrial vigente, foi amplamente reconhecida - sabe-se - tanto pelos defensores do modernismo e, mais ainda, do pós-modernismo, quanto pelos seus críticos. Não obstante, a admissão desse fato histórico - o qual não deixa de corresponder, vis-à-vis, a claro decréscimo de criticidade no universo das artes -, quando feita tomando-se como critério exclusivo de referência a lógica interna e até as idiossincrasias dos próprios movimentos mencionados (como se eles houvessem malogrado por si próprios, sem nenhuma ligação com o estágio tecnológico alcançado pela produção material da vida social), constitui enfático engano teórico. Na atualidade, em especial - há pelo menos três décadas de um processo avançado de mistura da arte à vida social -, é impossível prescindir de notar que a razão da decadência das vanguardas artísticas radica, em grande medida, justamente (embora de maneira inespecífica, indeterminada, sendo, por isso, dificil de comprovar empiricamente) no contexto cultural de saturação estética em que a atividade artística se insere, bem como no processo de dissuasão operada por esse contexto sobre tal atividade. ${ }^{40}$

40. Essa tese não pode (ou não poderia) ser objeto de descuramento acadêmico devido ao seu caráter sobremaneira especulativo. Por certo, trata-se, transparentemente, menos de uma hipótese de trabalho do que de uma proposição teórica. Como tal, ela se expõe privada, a contragosto, dos instrumentos 


\section{Buraco negro da nebulosidade estética}

Encerram-se, no quadro teórico-epistemológico anteriormente traçado, tanto mais aproximadamente quanto possível, as condições socioculturais e tecnológicas que se apresentam, cada vez mais profunda e radicalmente, como amplo e concreto quadro de fundo para toda e qualquer abordagem teórica e crítica atual (e, bem assim, para todo e qualquer procedimento empírico) no interior do universo artístico.

Os argumentos assentados formam, em conjunto, o que, a rigor, pode ser designado de horizonte negativo da arte - já, pois, realizado -, situação cultural indefinida e duvidosa quanto à sua natureza, em tudo um tanto fatídica quanto ao seu futuro, sem dúvida adversa na maioria dos aspectos, que coloca em cheque a sobrevivência da arte como fundação autêntica, bem como o seu sempre desejado impacto na circularidade dos fluxos significantes do social. ${ }^{41} \mathrm{~A}$ resplandecência ponderativa de um tal horizonte não sobreleva senão, por retroação, asserções anteriores - em suma: o lugar social da arte, se sempre restou vitimado por intempéries e vilipêndios na história, na era da estética da cultura tecnológica tornou-se tanto mais amplamente problemático. Se outrora imperavam fatores causais expressos na veemência centrífuga de uma alquebrada ventura econômica, de desumanas condições de saúde (dos representantes da arte) e da hostilidade burguesa (para vincular o assunto apenas ao passado recente) esta hostilidade que sempre anteviu na arte nada mais que ninharias, exceto quando os cifrões avultavam aos olhos, projetando promissores dividendos -, agora os fatores causais, sem tanta suspensão dos anteriores e dispondo-se em circularidade (na qual acabam por se confundir com os próprios efeitos), expressam-se como força diametralmente oposta, a saber, na forma da centripetação estrutural da familiaridade homeostática e positivișta que soa a voz comercial da metrópole, por

metodológicos necessários capazes de torná-la patente. A dissecação de suas mediações é, pois, tarefa que remanesce para a teoria - se é que um dia ela poderá ser devidamente cumprida.

41. A desinência do argumento requer, conforme nele mesmo notado, considerarse, no pormenor, para todos os fins do presente subtópico, tanto mais a arte que se quer autônoma, heterodoxa, movida diretamente pelo criticismo e, mais ainda, pela necessidade de confronto com a forma de organizaçāo do social e, por conseguinte, pela distinção. 
sua polpa como por seu invólucro, se assim se pode dizer. Essa preocupação com a condição da arte Baudrillard (1997, p. 153) a encaminha de maneira indagativa (não sem denotar, neste caso, certa melancolia camuflada):

$A$ arte (moderna) teve a oportunidade de integrar a parte maldita, sendo uma espécie de alternativa dramática à realidade, traduzindo a irrupção da irrealidade na realidade. Mas o que pode ainda significar a arte num mundo hiper-realista por antecipação, cool, transparente, publicitário? (...)

$A$ arte interpretando o desaparecimento do seu objeto, $e$ o seu próprio desaparecimento, ainda era uma grande obra. Mas e a arte tentando se reciclar indefinidamente apropriando-se da realidade?

Se, por um lado, na busca da assimilação, a arte, como manifestação antropológica integral, confunde-se com o movimento tecnológico do real que amplamente a barganhou; se suas materializações não conseguem mais, em si e por si mesmas, destacar-se do substrato que cimenta e matiza a arquitetura do complexo contextual genérico, tal fato não indica senão o quanto se tornou difícil, por outro lado, no plano da obra e de sua eficiência estética, bancar, com rigor, o jogo da diferença. Não obstante, diferenciar-se ou, em outras palavras - com a licença para o uso talvez indevido, embora muito oportuno, de uma metáfora astrofísica -, escapar do buraco negro da alta taxa de indistinguibilidade em relação à nebulosidade estética: eis um dos maiores desafios contemporâneos da arte. ${ }^{42}$

42. Horizonte negativo e buraco negro cavados, diga-se de passagem, pela própria arte em seu movimento de explosão extensiva, monopolizado e colonizado por seu braço mais teleológico-popular. Se, por conseguinte, eles agora se the aparecem como desafio, não é de se concluir senẫo que ela mesma assim os colocou, paradoxalmente, em seu caminho. (Veja-se, em complemento, a nota 57.) É condição que, de toda forma, não deixa, agora, de repercutir na teoria da arte. Assim como toda e qualquer reflexão contextualizada a respeito do vetor estético na sociedade tecnológica contemporânea não pode prescindir de levar em boa conta o avançado estado de saturação desse vetor, toda e qualquer consideração sobre o estatuto da arte nesse universo deve, igualmente, enfrentar a relativa ou cabal indistinção dela em relação ao conjunto e, por extensão, também a sua dissoluçāo. 
Se não se trata de um jogo impossível, tampouco se afigura fácil quanto à primeira vista possa parecer. A estipulação de uma "inconfundibilidade" estilística, formal e conteudística (seja em qual setor artístico for, sobretudo no que tange às artes visuais), mesmo quando bem talhada, não é mais argumento consistente, nem garantia de bom êxito no que tange ao enfrentamento desse desafio. ${ }^{43} \mathrm{Em}$ vista dessa incerteza e do ceticismo que dela promana, Adorno (s/d., p. 11) enceta, no ocaso da década de 60 do século passado, o seu

43. Poder-se-ia aventar, mais que outrora, que, em virtude da saturação estética, tudo o que diz respeito à arte e ao seu campo de produção próprio se demoveu para o terreno cifrado das sutilezas objetais. A arte só poderia, assim, ser reconhecida nestas e por estas, tanto mais porque elas concentram informações que valorizam a história e a autoridade da obra, ao mesmo tempo que, por ísso, são capazes de diferi-la, desde o pormenor, da "grosseria" estética environmental.

Esse juízo refaz, pois, o argumento da necessidade de conhecimento especializado prévio para habilitar-se à relação com a obra e com tudo o que diz respeito ao campo da arte. Para além da mera aquilatação, a consciência da natureza da própria arte estaria, segundo esse argumento, inextricavelmente atrelada a um melhor assesto do olhar, de um certo olhar, para ser enfático. Apenas a sensibilidade tecnicamente melhor preparada pela sociedade excludente para perceber nuanças - na hipótese de que estas dão acesso a significações mais profundas, que tanto presidem quanto rubricam uma obra - poderia (pốr-se como um) saber o que é, de fato, arte.

Se bem que contra tal argumento não pese acusação de ausência de veracidade - por mais essencialista, elitista e, pior ainda, evolucionista que ele seja (e o tem sido) -, não se pode dizer, tampouco, que ele tenha deixado de se relativizar amplamente, $e$ isto por razões que, a essa altura, o presente ensaio já deve ter tornado óbvias. A saturação estética, em seu turbilhão ou remoinho, concorre para transtornar e liquefazer de tudo um pouco. Do mesmo modo e com a mesma força que o excesso sobreleva a especificidade, ele a pulveriza no quadro de fundo de uma vertigem que faz fronteira com a obliteração.

$\mathrm{Na}$ contracorrente do mencionado argumento, deve-se reconhecer que, na era da saturação estética, um olhar do tipo indicado se tornou tão necessário, de maneira tão absurdamente absoluta, que ele mesmo já não existe mais em boa monta social para fazer frente à demanda contextual de sua existência. $O$ hiperexagero de sua premência técnica, forjado pelo excesso estético, acaba por não encontrar mais contrapartida prática, a sua devida e plena solvência; eis que ele cunha, assim, a própria impossibilidade de realização desse olhar. Uitrapassagem total da capacidade das singularidades pessoais pelo "estado da arte" da sociedade, sobrepujamento irreversivel e insolúvel, trata-se de um caso típico de sacrifício prévio por inexeqüibilidade, no grau de idealidade requerido pelo contexto.

Acresce ao exposto o fato de que, no atual estágio da estética da cultura tecnológica, o argumento em questão pouco resistiria a um cotejo entre, por um lado, as obras de cujas sutilezas ele se nutre para garantir sua legitimidade e, por outro, as diversas versōes semelhantes, senäo idênticas, a essas obras, (versões) comercializadas e difundidas - por empenho da reprodução técnica de alta definição ou mesmo da contrafação apurada -, isto obviamente menos do ponto de vista dos procedimentos técnicos empregados do que do dos resultados estéticos. De mais a mais, o problema posto não se esgota na aferição da legalidade do original, muito menos se resolve nesse domínio. $O$ argumento de legalidade, álibi moral de constrição à melhor assimilação do argumento ad auctoritatem, não supre a carência de consistência da tese da proeminência e sobredeterminação das sutilezas em matéria de arte. 
testamento estético com uma proposição peremptória - antecipada no subtópico 2, acima-e, ao que tudo indica, visionária, que recobra, a cada dia de enraizamento da estética da cultura tecnológica, mais validade:

Tornou-se manifesto que tudo o que diz respeito à arte deixou de ser evidente, tanto em si mesma como na sua relação ao todo, e até mesmo o seu direito à existência.

Pouco mais à frente, Adorno desfecha, em palavras palpáveis:

Não se sabe se a arte pode ainda ser possível; se ela, após a sua completa emancipação, não eliminou e perdeu os seus pressupostos. ${ }^{44}$

\section{Asfixia da "antítese social da sociedade"}

Um desdobramento bem assestado dessa tendência argumentativa, mesmo em nome de uma radicalização mais acentuada das hipóteses teóricas, só não faz que reforçar o que os meandros subentendidos de tal tendência o conseguem, a contento, por si próprios.

44. Sublinhe-se, com efeito, que as assertivas reproduzidas Adorno atira, de certa forma, contra a sua própria vontade teórica, reivindicando, para a sua concepção estética, um espaço de honra para a riqueza flexível da (na falta de melhor palavra) "ambigüidade" no plano do conceito, criadora do jogo e da complexidade simbólica. Para além da tese do desaparecimento da arte, Adorno (ibid., p. 14) aposta na preexistência e na prevalência fundamental de um substrato indestrutivel que, mais que presente na arte, a preside:

Actualmente, a estética não tem nenhum poder sobre se virá a ser ou não o necrológio da arte, mas também não deve brincar às orações fúnebres; não tem em geral que constatar o fim, reconfortar-se com o passado $e$, independentemente de seja a que título for, transitar para a barbárie como represália pelos seus excessos bárbaros. O conteúdo da arte passada, mesmo que a arte possa agora estar suprimida, suprimir-se, desaparecer ou prosseguir no desespero, não deve necessariamente caminhar para o seu declínio.

Nessa perspectiva, tanto faz qual seja a condição concreta de manifestação de um resultado estético. "A arte poderia ter o seu conteúdo na sua própria efemeridade." (Ibidem.)

Qualquer vertente fenomenológica em filosofia, na contracorrente do pensamento adorniano, vincularia imanentemente uma coisa à outra - vale dizer, a arte e o seu substrato (conteúdo), obra e situação -, fazendo, pois, delir-se uma no momento em que se acusasse o comprometimento da respiração da outra. 
O universo estético, inflado por uma espécie de arte por demais sinérgica, inviabiliza, paradoxalmente, a própria arte, pela deportação de sua genuinidade. Quanto mais a arte se põe em nome de sua integração ao todo, mais ela se exila de si própria, despachando-se para o nada. ${ }^{45}$ Em outros termos, a mesma estética que realiza, por um caminho, a arte é aquela que, por outro, relativiza as suas possibilidades políticas e culturais (embora nunca tarde a afirmar suas possibilidades econômicas, promitente córrego de morte), através do bloqueio ou minoração de sua melhor pulsação, via profusão descomunal de produtos artísticos. De outro ângulo ainda num enfoque mais detido -, o modelo de arte que, ao longo do tempo, de braços dados com o valor de troca, granjeou predominância rechaça, por abraço aberto e doce deglutição que a tudo anulam, a arte autônoma e heteróclita. ${ }^{46} \dot{E}$ assim que, como ato instituinte singular e autêntico de uma "antítese social da sociedade" (Adorno, s/d., p. 19), a arte acaba por sofrer um processo de asfixia.

Se esse acontecimento de desterro, de dissuasivo estorvamento e de obliteração é paradoxal, é menos pela lógica nele inscrita do que por seu caráter permanentemente intrigante: conforme antes sugerido, quanto mais um contexto se torna pleno de determinado elemento, este, ao contrário de existir mais e melhor, fenece pela quintessência de sua própria redundância. Assim se passa com a arte: ela é, em boa medida, uma vítima tecnológica de sua própria banalização tardocapitalista, pós-moderna. Não por acaso, o fetichismo estético integral pode melhor fetichizá-la: o que jaz tem maior propensão a se tornar fetiche. A este tudo o que se concebe vivo costuma render alguma forma de culto.

\section{Deslocamentos sintomáticos da produção artística}

Para sobreviver, livre da obliteração que lhe saqueia o melhor brilho, e recobrar sua função social-histórica, a arte necessita

45. Em ressonância às notas 24 e 34 , não é demais pontuar, en passant, que esse nada é óbvia e inteiramente distinto daquele de que, no mesmo contexto, fala Baudrillard.

46. Comentando a perspectiva de Hegel acerca da morte da arte, Adorno (s/d. p. 14) expressou-se de maneira enfática:

A revolta da arte, teleologicamente posta na sua 'posição relativamente à objectividade' do mundo histórico, transformou-se na sua revolta contra a arte; é inútil profetizar se ela the sobreviverá. 
recolocar-se em novas bases. A esse respeito, uma das principais tarefas reflexivas do presente é justamente saber melhor quais são essas bases e aferir quais as efetivas possibilidades de tal redefinição. ${ }^{47}$

Nunca como hoje, no delírio da nebulosidade estética, foi tão premente, por exemplo, (re)fundar a arte da arte. ${ }^{48}$ Mais que outrora, a arte carece não de uma qualquer metalinguagem, mas de uma sua própria, forjada por ela mesma, a fim de reelaborar a autoconsciência tanto da natureza processual prática de seu mister e de sua inserção na dinâmica cultural, quanto, principalmente, do seu movimento social-histórico.

Seja como for - e em que pese boa parte dos argumentos expostos no subtópico 2, acima, e no anterior -, é isto o que, em boa medida, tem-se testemunhado nas últimas três décadas, no âmbito da empiricidade dos próprios processos.

Porque a arte, de par com a vida - com a qual construiu sua história de mimese -, tem fome vida, ânsia por reprodução e perpetuidade distintivas (por mais que pressuponha ou exiba a morte a todo instante, via iconografia, sonoridade e textualidade prolíficas), ela, como requintada herdeira de Fênix, busca, por meio de suas vertentes contemporâneas (sobretudo mais heterodoxas), sem tantas ilusões quanto ao desejo teleológico-vanguardista, içar respostas reativas ao existente, através da elaboração de deslocamentos socioculturais e transpolíticos contínuos, a fim de burlar o que lhe neutraliza a partir das entranhas. ${ }^{49}$

47. Tarefa que, cabe enfatizar, concerne tanto ao labor teórico-prático representativo do campo artístico, quanto aos setores de produção cognitiva que lhe são (aparentemente) exteriores, em especial a filosofia e a sociologia. No que concerne àquele labor, o desafio antes mencionado o mundo tende a legar como prerrogativa de artistas-intelectuais afeitos especialmente a nuanças tanto dos modos diversos de produção da obra, quanto da relação entre a natureza desta e a estrutura do contexto. Trata-se, mais que isso, de um desafio aberto àqueles que não se furtam em responder à ameaça pantópica à dignidade da arte por meio de um levar, mais que a obra, o processo teórico-prático da arte com pinça e lupa, para usar uma expressão prosaica, pela força e justeza de sua semântica.

48. O que - não há razão para confundir-se - pouca relação tem com a motivação autista da arte pela arte (muito menos com as "façanhas artísticas da própria arte"). Trata-se, antes, de uma arte fadada a tornar-se objeto de si mesma mas em direçāo muito diversa, a daquela em que o pólo cognoscitivo, mantendo-se aberto ao mundo, lança estrategicamente uma reflexão contínua sobre si próprio, entrega-se a um inteiro (re)pensar-se; em suma, de uma arte continuamente auto-reflexiva (para além da própria estética, inclusive), alerta ao jogo (mediático e não-mediático) do contexto.

49. Adorno (s/d., p. 28) já havia percebido o problema: 
Registrem-se, a grandes traços sinalizadores, alguns desses desvios arbitrários, dessas mudanças estratégicas de rota. ${ }^{50}$ Se a incorporação da arte ao processo produtivo e a sua reprodução serial por meio da tecnologia comprometeram a unicidade e a autenticidade do objeto artístico, a arte promoverá, mais intensamente, o deslocamento da aura, fazendo-a recair no processo de elaboração estética, em vez de no produto final: a arte se auto-afirma como hiato vivo, como durante criador, como enquanto intenso - única "ambiência" (atmosfera-locus) que se colocaria como fonte exclusiva de sentido de vida no âmbito artístico -, após o que tudo, mormente a obra, resta enquadrado na cláusula do morto. Se o excesso de produtos artísticos industrializados e a multiplicação infinda de suas reverberações sociais no plano do significante operam - nos termos antes demonstrados - uma reversão da promessa estética, na forma de um processo de anulação generalizada que amaina, por sua vez, a eficácia da unidades artísticas, a arte vai, mais que nunca, perseguir, obsessiva e quase metodologicamente, o choque anti-comercial (e todos os seus derivativos), o abalo emocional, a descarga energética, a produção de estranheza, a devastação do pudor, até a repugnância, explorando a fronteira com todas as modalidades de sensacionalismo mediático e fazendo da impressão fatal, inapagável, do bizarro menos uma proposta estética iluminista de desconstrução e reeducação dos sentidos do que uma nutriente esperança de longa sobrevida para si (arte), assim resolvendo, por ilusório que seja, a equação contemporânea de sua condição sitiada. ${ }^{51}$ Nessa direção, a arte emprega pedaços de roupas destroçadas de vítimas de guerra; estimula a práxis de obras feitas com pele, sangue, esperma humanos; estampa imagens de corpos moribundos soropositivos; incorpora animais esquartejados em estado de putrefação quimicamente controlada; instrumentaliza a nudez de seus próprios representantes,

A arte não reage à perda da sua evidência apenas através de modificaçöes concretas do seu comportamento e dos seus procedimentos, mas forçando a cadeia que é o seu próprio conceito: o de que ela seja arte.

50. A tarefa é cumprida suspendendo-se, no momento, a sistematização de exemplos concretos.

51. De qualquer forma, a lógica que preside esse e outros deslocamentos (abaixo aludidos) resulta óbvia: porque a saturação estética vigente narcotiza, por assim dizer, os sentidos, é preciso, ao menos, sacudi-los, e bem. 
genitálias à mostra; e assim por diante. ${ }^{52}$ Se o princípio valorativo predominante na estética da cultura tecnológica é o da(o) construção/construtivismo ou, na pior das hipóteses, o da destruição domesticada, comercial, portanto inócua, a arte, por seu braço perverso mais radical, vai, na esteira do choque, empenhar fidelidade à destruição real (mediante algum tipo de documentação visual), admitindo situações que, por mais que incorporem a simulação e a dissuasão, implicam mortes verdadeiras. ${ }^{53}$ Se o fetichismo estético integral é talhado pela lógica do visível, a arte, em percurso mais raro, devotará apreço ao pólo oposto: abrindo caminho para a invisibilidade como estilo, fabricará pinturas em miniatura para serem vistas tanto melhor com lupa. Se a estética generalizada é, em suas unidades formais, opaca e, de certa forma, inflexível (no que respeita à relação entre sujeito fruidor e objeto, na qual só há lugar para a prática da contemplação dentro de condições de contigüidade corporal ao produto cultural), a arte não tardará a abraçar - seja através da previsão de procedimentos práticos de recepção que definam, eles sim, a obra, seja através do uso de suportes técnicos imateriais, fluidos, voláteis - o modelo da participação interativa, própria da área informática (estendendo, inclusive, de maneira indiscriminada e totalmente inapropriada, o sentido desse modelo para contextos de recepção não-informáticos), com o objetivo de, enfim, facultar ao sujeito a possibilidade de inserção na obra. ${ }^{54} \mathrm{Se}$, nessa mesma esteira, o olhar e a audição constam alçados ao patamar de sentidos predominantes, em detrimento dos demais, a arte, respondendo por outra

52. De se notar, en passant, que o próprio sistema publicitário, amplamente carente de cenários a cada vez mais impactantes, assenhorou-se - Benetton à frente de algumas dessas sugestões, propostas e/ou tendências artísticas, o que só confirma a voracidade da estética da cultura tecnológica, por seu vetor mediático.

53. Se é que o descrito pode ser chamado genuinamente de arte.

54. No que toca ao universo virtual, a imagem numérica, considerada em seja qual recorte for, on-line ou off-line, é disso nẳo somente um exemplo em abundância, senão ainda a condição sine qua non para a efetividade mais sofisticada dessa inserção. Comparecem aqui a infografia, a Web art e outras modalidades de arte digital.

A exemplo da observação feita na nota 52 , lembre-se, com efeito, que, além de essa reserva de intervençẳo já fazer parte da própria estética da cultura tecnológica, o universo mediático áudio/visual (de massa e interativo) como um todo tem, nessa característica, a sua pedra angular, técnica e plenamente realizada desde, pelo menos, as duas últimas décadas do século passado, com a peculiaridade de, no caso, não se tratar, em absoluto, de arte. Como estratégia de disputa de mercados de audiência, o sujeito é sempre "convidado" (e vigiado) a realizar incursões em cadeia: no objeto tecnológico, no produto cultural, nas redes comunicacionais, via solução 
política da percepção em escala sociocultural, reivindicará, mais ainda, em paralelidade à produção do choque como estratégia estética, uma relação diferente com os sentidos desprezados (fadados, como tal, a uma atrofia antropológica ainda não de todo aferida), cavando neles a ondulação reflexiva ou a agitação crítica que a estética da cultura tecnológica não é capaz de produzir, por descrédito óbvio: a arte radicalizará, por exemplo, a sua consubstanciação em obras (de pequeno a grande porte) - feitas de guloseimas - destinadas a “desautomatizar" o olfato, a esgrimir o paladar e a convidar à (não raro, interdita) interação tátil (confundida com interatividade) com as mesmas. ${ }^{55}$ Se um dos calcanhares de Aquiles do universo estético é a duração (em virtude seja da natureza de seus suportes, seja de seus modelos hegemônicos), a arte se porá, mais que nunca, em busca de materiais e elementos perecíveis ou de procedimentos estéticos propositadamente ultravulneráveis ao transcurso do tempo: ${ }^{56}$

instrumental de participação (telefonia, fax, e-mail, chat etc.). Já não basta, no contexto de recepção mediática, manter-se próximo ou justapor-se ao aparelho de base, a fim de encetar o consumo simbólico, por mais atento e auto-consciente que este seja; é preciso "entrar" e cumprir o ritual da participação. Não se tenha dúvidas: no compasso das décadas, as necessidades mercadológicas estruturais do sistema mediático não o fazem senão engendrar soluções tecnológicas e sugerir procedimentos sociais que só intensificam e aprofundam o seu caráter autoritário ou, melhor, totalitário, ao mesmo tempo em que esse sistema os adocica vivamente, como forma de dissuasão, no que toca tanto a cada pormenor, quanto ao efeito de conjunto. Posto que a questão implica, em seu centro, a imagem, cabe ressaltar que esta é a sua fase mais atual e, em muitos casos, socialmente maciça, que propende para uma maior banalização mundial nas próximas décadas. Sobre esses temas, veja-se Trivinho (1999, Parte I, Capítulo VIII, e Parte II, Capítulo V; e 2001, p. 187-207).

55. Tatilidade que, dependendo da proposta estética em jogo, é arbitrariamente prevista como fator inexorável de autodestruição da obra $e$, bem assim, como termômetro fidedigno da resposta do público.

56. Em especial, a Web art, criação estética elaborada exclusivamente para o filão multimediático do cyberspace, mencionada na nota 54, é menos uma arte ligada ao vetor espacial que ao vetor do tempo - do tempo tecnológico, tempo real, tempo, pois, perdurável, por mais que radique na origem de processos sociais e manifestações culturais efêmeros.

Por fincar-se no universo eletrônico imaterial, socialmente irradiado através de terminais videográficos, trata-se de uma arte cuja fenomenologia somente se entrega mediante acionamento do equipamento de acesso a tal universo. A "contemplação" de uma obra assim regulada, bem como a exploração de suas possibilidades e potencialidades por meio de recursos interativos condicionam-se a uma provocação de base (para evocar e contextualizar um conceito caro a Heidegger). Caso contrário, para todos os efeitos, a Web art, como fenômeno, não existe; permanece "estocada", em estado (por assim dizer) de latência, em inteira disponibilidade, porém fora do campo da visibilidade.

Á sombra do arco que abrange desde a opacidade e inflexibilidade dos modelos e tendências da arte que sustentam a estética da cultura tecnológica até a perdurabilidade dessas produções artísticas, a Web art aposta numa vereda híbrida, dificilmente apreensível sem a consideração dos devidos interstícios. 
em ambos os casos, abrir-se-á à pura efemeridade, com obras destinadas à autodesintegração, patenteando-se, por isso e além de tudo, no seio da morte, como arte do desaparecimento. ${ }^{57}$ Enquadram-se nessa tendência - mais que em circunstâncias acima subentendidas - as instalações artísticas. ${ }^{58} \mathrm{Se}$, no contexto do fetichismo estético vigente, a arte, circunscrita ao reino da substancialidade de um valor

57. É justamente em torno desse desejo inaudito de auto-obliteração, pulsátil na arte contemporânea, que a propensão programada ao efêmero motiva alguns comentários. A arte nunca teve, aliás, nenhum medo da morte. Trata-se aqui, no entanto, de sua própria morte - por mais sazonal, esporádica ou reversível que seja -, no âmbito de uma estética bem demarcada.

As nuanças que mediam essa tendência artística e as características estruturais do contexto estético estudado no presente ensaio - nuanças que migram de um lado a outro, sem, no entanto, dar-se tão imediata e facilmente à percepção teórico-conceitual - podem, eventualmente, causar ainda confusão (ou reforçála) no que concerne à relação dessa tendência com o desaparecimento da arte operado difusamente pela estética da cultura tecnológica, conforme referenciado no final dos subtópicos 2 e 5 do tópico III, acima. Estratégia reativa consciente, egressa de proposta estilístico-metodológica definida, o desaparecimento correspondente à inclinação artística em questão não é, contudo, nem de longe, da mesma ordem daquele tipo de desaparecimento; sob tal ponto de vista, não poderia, portanto, enquadrar-se nele, por mais que, de outro ângulo, os resultados estéticos em jogo possam porventura sê-lo, com todas as tintas.

O desaparecimento objeto desta nota significa trabalho estético-cultural com o tempo como matéria-prima manipulável, quase como outra qualquer no universo da arte. Contestando tanto a perdurabilidade áudio/visual do fetichismo estético integral, como, de resto, toda a tradição de durabilidade das obras de arte, esse desaparecimento pode tanto ser absoluto, de duração infinita, na modalidade de um estado defectivo estrutural, como tal irreversível - o que até poderia fazer erroneamente supor não deixar ele, no caso, de convergir para a (radicalização da) hipótese do horizonte negativo da arte -, quanto pode ser relativo, intermitente, de caráter periódico ou aleatoriamente cíclico, dependente de condições específicas do campo e do mercado da arte. Nesse mosaico, uma obra - aqui uma instalação (como a próxima oração do próprio texto dá disso conhecimento, junto com a nota correspondente) - pode fazer-se visivel em determinado momento e, ainda nele mesmo, desintegrar-se para sempre, não se exibindo depois senão exclusivamente em material documental-pictográfico; ou pode dar-se à luz em momentos oportunos, por desintegração e reimplantação em lugares e circunstâncias diferentes. Em ambas as vertentes, o desaparecimento, porque previamente arquitetado, pertence inextricavelmente à própria obra e ao processo que ela, em si, representa; mais ainda, define-os, na verdade, exalando, ele mesmo, como tal, já, arte. A respeito dessa temática, registrou-se em outra oportunidade (Trivinho, 1998b):

Toda concepção de obra de arte como instalação - sem contar aquela que a encara como processo, como um fazer apenas, não importando o resultado material dai proveniente - é um exemplo de arte que, nada mais tendo a ver com o tempo das longas duracōes (característica exclusiva da produção estética desde a antigüidade clássica até o século $X X)$, dispensa a sua perpetuação [como tal], descarta o seu lançamento [como obra] para a posteridade; vale dizer, tendo por referência o tempo curto, denega o tempo ao advogar o próprio desaparecimento nele.

58. Em adendo à nota anterior, recorde-se que as instalações artísticas, em geral identitárias ao esquema da autenticidade do único, por mais que se exponham além de uma vez - nisso estando de par com o teatro -, são um caso exemplar de 
de troca funcional e pragmático, carece de um dimensionamento objetal quase incondicional - exceção feita, nesse aspecto, à arquitetura -, ela vai, então, esmerar-se em aumentar o seu raio horizontal e vertical de projeção pública, realizando, a céu aberto, no espaço urbano, instalações de traços desmedidos e imponentes: envolvendo megamonumentos, efeitos especiais a laser e outros recursos aparatosos, deseja tragar a cidade inteira, de modo estéticoprocedimental contrário à doxa. Se, na mesma esteira de prolificação do valor de troca, a arte alinhada à estética da cultura tecnológica lança ao mundo, a todo instante, produtos e serviços em/através de suporte físico convencional (incluso todo e qualquer material eletrônico de tipo analógico), reforçar-se-á, sobretudo na orbe das metrópoles e cidades médias mais desenvolvidas, o encontro entre arte e carne, em todas as modalidades da body art, o corpo se instituindo, pela técnica e pela tecnologia, como campo de registro estético, mormente quando irreversível. ${ }^{59}$

Todos esses deslocamentos de foco e ação estéticos - como eles mesmos se deixam apreender - constituem algo sintomático em si mesmos. ${ }^{60}$ Não sendo cumulativos, mas podendo, por evidente, comparecer alternativamente mesclados, eles comunicam, antes de

busca do deslocamento da aura, de que falava Benjamin. O sucesso do empreendimento é tanto mais radical e conseqüente quanto a instalação-evento se esgote na vez em que se realiza - vale dizer, entregue-se ao desaparecimento absoluto - e não seja reproduzida por nenhum meio, sobretudo audiovisual, caso em que se perpetua tão-somente na e pela memória do público presente. Seqüência prétecnológica rara - senão absurda, impossivel - nos dias atuais.

59. Pensando-se, em especial, nas tatuagens: esse cruzamento fatal entre arte e carne, que demonstra e põe na ordem do dia a potência histórico-antropológica de cenários culturais originários ou, ao menos, imanentemente conexos à natureza, vê-se representado, ao nível teórico mais abstrato, pela junção inextricável entre o imaginário residual das condiçōes de uma vida humana tecnologicamente primitiva, própria da floresta, e a consciência das possibilidades infra-estruturais avançadas das zonas metropolitanas. Reinvenção artística (socialmente estabilizada) por regressão histórica.

60. Vale lembrar, en passant, que eles se dispõem, a rigor, na mesma direção de experiências precedentes recentes e bem conhecidas, delas se distinguindo, no entanto, ao dilatar, distender e matizar o seu substrato (a saber, o desvio estratégico), levando-as às últimas conseqüências: entre outros exemplos, a exploração política (lato sensu), via estética, de certos tabus, como resposta direta ao conservadorismo moral; e o retorno à arte artesanal promovido pelo movimento hippie nos anos 60 do século passado, como reação política e cultural à estética serial da produção industrial. (A respeito do último caso, não é de todo dispensável dizer que, passadas mais de três décadas, toda e qualquer proposta de retomada desse ideário não deixa de soar reacionária, rósea nostalgia de uma estética pré-tecnológica que os dias hodiernos tem equacionado ao cume da melancolia política.) 
mais nada, a situação geral da arte como movimento ontoantropológico diversificado, não raro cifrado numa dimensão inacessível a uma satisfatória apreensibilidade; e, ainda, mostram que a referência básica para a afirmação das tendências artísticas neles fincadas são, mais que nunca, não as injunções internas a estas e, por extensão, as rupturas de que se nutrem, mas a especificidade histórica do contexto tecnoestético integral. Se, em sua sinuosa trajetória, aprouve normalmente à arte responder ou remeter-se ao todo (por fraturado que ele sempre possa ter-se apresentado) - o que não significa, necessariamente, reivindicação de integração a ele, nem a priori, nem $a$ posteriori -, agora essa rubrica vê-se tanto mais coroada de veracidade.

\section{Incerteza do devir, atelia e defecção da esperança}

Não obstante, a lógica dos deslocamentos apontada, por não se assentar num eixo comum e por apontar simultaneamente para diversas direções - fato que, aliás, não é somente positivo, como também sedutor -, oferece um ensinamento ainda mais fundamental. A teoria estética e social que sempre vinculou à arte, de forma imanente, um projeto ou desejo teleológico apriorístico restou significativamente arruinada. Ao contrário do que, no caso, estampam enganosamente as aparências, a arte, abalada em seu vir-a-ser na era da saturação estética, fonte dissimulada e despercebida da vertigem de seus rumos, não é mais depositária de nenhuma esperança fundamentalmente crível e creditória. De par com a maioria das práticas hodiernas, sobretudo no âmbito das metrópoles e cidades médias, a arte tornou-se, a rigor, uma atividade sem devir definido, ${ }^{61}$ no que respeita ao impacto (aqui, mais político que cultural) de suas propostas. Se, como Adorno costumava argumentar - e supondo-se ainda apropriada ao caso a sua perspectiva teórica -, a inutilidade social subjacente ao processo constitutivo da arte sempre foi, para esta, a garantia radical de seu maior potencial crítico e um dos pontos de honra de seu estatuto histórico na

61. A esse respeito, ela é, aliás, uma espécie de timoneira dessas práticas, a contar que o substrato de tudo o que ocorre de inédito e profundo na sociedade não deixa de pulsar antes na sensibilidade dos que laboram - com ou sem consciência histórica - no campo artístico. 
cultura totalitária do utilitarismo e do valor de troca, ${ }^{62}$ essa caução meritória vê-se, na atualidade - ao menos por enquanto - , cumulativa e marcantemente indexada pela atelia ou, se se quiser, pela hipertelia. ${ }^{63}$ Esse acontecimento, cuja evidência de ser apenas conjuntural pode induzir a equívoco de interpretação, não somente salienta, como também - e principalmente - estressa às últimas consequiências (senão implode) a apreensão dialético-hegeliana, por Adorno (s/d., p. 13), da arte no processo histórico:

\section{A definição do que é a arte é sempre dada previamente} pelo que ela foi outrora, mas apenas é legitimada por aquilo em que se tornou, aberta ao que pretende ser e àquilo em que poderá talvez tornar-se.(...) O ter-estadoem-devir da arte remete o seu conceito para aquilo que ela não contém. (...) A arte só é interpretável pela lei do seu movimento, não por invariantes. Determina-se na relação com o que ela não é.

Por certo, nem sempre ausência de telos equivale necessariamente a suspensão da esperança. ${ }^{64}$ Fique claro, porém, por um

62. Nos termos da dialética de Adorno (s/d., p. 15): "A identidade estética deve defender o não-idêntico que a compulsão à identidade oprime na realidade".

63. $\mathrm{Na}$ acepção que the confere Baudrillard (1983): alucinação implosiva da finalidade, por excesso [daquilo que pretendia ter (ou mesmo tinha) alguma meta intrínseca a ser cumprida].

64. Dispensável consignar, a essa altura, que a argumentação do presente ensaio não desacredita, muito menos nega, a validade hodierna (e doravante) da produção artística, sobretudo a de vertente heterodoxa e crítica, que não fecha com a forma de organização e funcionamento do existente, tanto no âmbito técnicopragmático, quanto no âmbito mais abstrato, imaginário, valorativo.

Em evocação a passagens da nota 1 , a argumentação apenas cartografa o (novo) contexto de fundo da arte, a crítica incidindo, a todo tempo, mais sobre este, com certa pressão nas tintas, como política de reflexão teórica, para a otimização da epistème.

$O$ pếndulo postural básico do presente estudo - a saber, nem a concessão teórica de apoio exclusivo, melancólico, a formas, esquemas e contextos artísticos do passado, nem tampouco a de apoio político-ufanista a formas, esquemas e contextos artísticos que mais não fazem senão reforçar a estética da cultura tecnológica - pode realmente causar mal-entendidos, fato que se intensifica mais ainda em virtude de o presente ensaio nāo estar alinhado nem ao essencialismo da estética moderna de Adorno, nem ao niilismo irônico do pósmodernismo de Baudrillard acerca do descartável destino da arte, e isto mesmo que, em pontos nevrálgicos da perspectiva teórica aqui adotada, possa com eles concordar amiúde - de modo simultâneo -, em que pese tratar-se de perspectivas teóricas, epistemológicas e metodológicas diametralmente opostas. (O resultado filosófico da descrença conscientemente conquistada de Adorno comunga, no que toca à arte, com o resultado teórico do nilismo inegociável de Baudrillard. Evidência que não deixa de ser paradoxalmente curiosa.) 
lado, que a esperança defectiva, aqui referida, é a que ressoa o clamor de uma essência última, de um fundamento de base, de uma verdade unitária. Essa esperança, que durante toda a era das ideologias, desde pelo menos o século das Luzes, impregnou a arte, dissolveu-se por completo na derradeira crise dos valores e metarrelatos tradicionais e modernos a partir da Segunda Guerra Mundial (Trivinho, 2001, p. 39-78). Sublinhe-se, por outro lado, não estar, nem de longe, também em jogo aqui nenhuma esperança de tipo artificial promovida diuturnamente pelos telos institucionais (a saber, o das corporações bancárias, dos institutos previdenciários e de pecúlio, das administradoras de planos médicos e cartões de crédito, das companhias de seguro, dos cassinos, e assim por diante), todos eles dependentemente insuflados pela linguagem publicitária do sistema mediático, este mesmo o maior e mais legítimo negociante atual de ilusões teleológicas, semeadas por todo e qualquer produto cultural e mesmo nas entrelinhas da programação diária. Esse tipo de esperança a arte que não se verga à doxa e preza o seu próprio nome se encarregou há muito de varrer de seu vocabulário, deixando-a com prazer à variedade de arte que faz da sinergia com a estética da cultura tecnológica o seu modus vivendi. A arte - ressalte-se - prescinde, pois, de ambos esses zelos de fé. ${ }^{65}$

Não é improvável que deixe de residir justamente nessa defecção de esperança, nesse seguir atélico específico - nos termos demarcados -, o diferencial contemporâneo da arte: seu maior trunfo, subsumido em seu atual potencial crítico, seria, nessa perspectiva, o niilismo visceral quanto a si mesma, ao contexto social-histórico e ao seu lugar e estatuto nesse contexto. ${ }^{66} \mathrm{Tal}$

65. Se é possível afirmar algum tipo de esperança que evite, simultaneamente, a impostura viciosa de uma visão fundamentalista e o ufanismo das certezas por uma transcendência teleológica - formas de relação com o mundo não raro gêmeas, esta última abrangendo toda e qualquer volúvel aposta em seja qual for a noção pragmática e positivista de futuro, em especial a ingenuidade política em relação aos finalismos operacionais do sistema tecnológico e comunicacional instituído -, não é matéria de discussão do presente ensaio. É bem possivel, no entanto, que a arte e/ou o campo laborioso que responde por ela já viva(m) há tempos esse tipo de esperança, e isto por mais problemática que seja a própria categoria da esperança - por exemplo, ela dança voluptuosamente no ponto de encontro entre a linha sintagmática do futuro e a linha paradigmática da barbárie - e por mais difícil que seja desvinculá-la dos procedimentos existenciais antes mencionados.

66. Se a arte, assim inclinada um pouco mais à heterodoxia, pode - como já o faz desbravar novas fronteiras, depende inteiramente de sua ebulição criadora, no que toca especialmente à relação consigo própria, em resposta à época. 
assertiva é, não obstante, lançada com larga distância em relação à anti-aposta cético-irônica de Baudrillard (1997, p. 156) na arte, crença desiludida que congela a priori esta última num futuro de pulsação artificial, no qual a única motivação existencial em jogo se esgotaria na simulação infinita da auto-legitimidade própria. Em suas palavras:

A arte terá direito a uma segunda existência, eterna semelhante a dos serviços secretos que, como sabemos, não têm mais, depois de muito tempo, segredos para roubar ou trocar, mas não deixam de florescer, protegidos pela superstição de sua utilidade e chamando a atenção da crônica mitológica.

Os deslocamentos antes assinalados - um par deles de clara resistência cultural sublimada pela estética -, por mais flácidos e metastáticos que sejam, acenam com o descarte de tal aridez espargida, mesmo que o quadro de fundo analisado no presente ensaio esteja permeado pelo nonsense.

Independentemente da taxa de equívoco ou acerto de tais apontamentos, eles não têm senão por mérito atrair a atenção para o fato de que, mais que nunca, a estética da cultura tecnológica repõe (e, ao mesmo tempo, justifica) a indagação fundamental que entrecorta o fio dos tempos e que há anos se lança para o encantador frontispício de um horizonte negativo: que, de fato, quer-se dizer quando se diz "arte"?

\section{Bibliografia}

ADORNO, T. W. s/d. Teoria estética. Lisboa: Ed. 70.

ADORNO, T. W.; HORKHEIMER, M. 1970. Dialéctica del iluminismo. Buenos Aires: SUR.

BAUDRILLARD, J. 1976. L'échange symbolique et la mort. Paris: Galimard.

. 1981. Simulacres et simulations. Paris: Galilée.

. 1983. Les stratégies fatales. Paris: B. Grasset. 

Mediações).

1996. O crime perfeito. Lisboa: Relógio D’Água (Coleção 1997. Tela-total: mito-ironias da era do virtual e da imagem. Porto Alegre: Sulina.

BENJAMIN, W. 1978. "A obra de arte na época de sua reprodutibilidade técnica". In: Costa Lima, Luiz (org.). Teoria da cultura de massa. Rio de Janeiro: Paz e Terra, p. 209-244.

CELAN, P. 1999. Cristal. Sel. e trad. Claudia Cavalcanti. São Paulo: Iluminuras.

DEBORD, G. 1971. La société du spectacle. Paris: Champ Livre. . 1988. Commentaires sur la société du spectacle. Paris: Gérard Lebovici.

KROKER, A.; COOK, D. 1988. The postmodern scene: excremental culture and hyper-aesthetics. Houndmills: Macmillan.

HEIDEGGER, M. 1978. Introdução à metafísica. Rio de Janeiro: Tempo Brasileiro, UnB (Biblioteca Tempo Universitário).

HAUG, W. F. 1997. Crítica da estética da mercadoria. São Paulo: Unesp.

JAMESON, F. 1997. Pós-modernismo: a lógica cultural do capitalismo tardio. São Paulo: Editora Ática.

MANDEL, E. 1985. O capitalismo tardio. $2_{-}^{\text {a }}$ ed. São Paulo: Nova Cultural.

MARCUSE, H. s/d.a. Eros e civilização. Rio de Janeiro: Círculo do Livro.

. s/d.b. A dimensão estética. Lisboa: Edições 70.

1967. A ideologia da sociedade industrial. Rio de Janeiro: Zahar.

. 1970a. Cultura y sociedad. Buenos Aires: SUR.

. 1970b. Ética de la revolución. Madrid: Taurus.

1978. "A arte na sociedade unidimensional". In: Costa Lima, Luiz (org.). Teoria da cultura de massa. Rio de Janeiro: Paz e Terra, p. 243-256.

MARX, K. 1983. O capital. São Paulo: Abril Cultural, v. I, livro primeiro, t. 1.

SFEZ, L. 1994. Crítica da comunicação. São Paulo: Edições Loyola. TRIVINHO, E. 1998a. Redes: obliterações no fim de século. São 
Paulo: Annablume/FAPESP.

1998b. "Notas sobre o tempo na sociedade tecnológica". São Paulo: cópia reprográfica, 4 p.

1999. Cyberspace: crítica da nova comunicação. São Paulo: Biblioteca da ECA/USP, 466 p.

2001. O mal-estar da teoria: a condição da crítica na sociedade tecnológica atual. Rio de Janeiro: Quartet.

VIRILIO, P. 1984. L'horizon négatif: essai de dromoscopie. Paris: Galilée. 